San Jose State University

SJSU ScholarWorks

Master's Theses

Master's Theses and Graduate Research

1989

\title{
Special academic needs students in private elementary education in Santa Clara County
}

Kathleen R. Lindsay

San Jose State University

Follow this and additional works at: https://scholarworks.sjsu.edu/etd_theses

\section{Recommended Citation}

Lindsay, Kathleen R., "Special academic needs students in private elementary education in Santa Clara County" (1989). Master's Theses. 3086.

DOI: https://doi.org/10.31979/etd.qn45-nkf5

https://scholarworks.sjsu.edu/etd_theses/3086

This Thesis is brought to you for free and open access by the Master's Theses and Graduate Research at SJSU ScholarWorks. It has been accepted for inclusion in Master's Theses by an authorized administrator of SJSU ScholarWorks. For more information, please contact scholarworks@sjsu.edu. 


\section{INFORMATION TO USERS}

The most advanced technology has been used to photograph and reproduce this manuscript from the microfilm master. UMI films the text directly from the original or copy submitted. Thus, some thesis and dissertation copies are in typewriter face, while others may be from any type of computer printer.

The quality of this reproduction is dependent upon the quality of the copy submitted. Broken or indistinct print, colored or poor quality illustrations and photographs, print bleedthrough, substandard margins, and improper alignment can adversely affect reproduction.

In the unlikely event that the author did not send UMI a complete manuscript and there are missing pages, these will be noted. Also, if unauthorized copyright material had to be removed, a note will indicate the deletion.

Oversize materials (e.g., maps, drawings, charts) are reproduced by sectioning the original, beginning at the upper left-hand corner and continuing from left to right in equal sections with small overlaps. Each original is also photographed in one exposure and is included in reduced form at the back of the book. These are also available as one exposure on a standard $35 \mathrm{~mm}$ slide or as a $17^{\prime \prime}$ x $23^{\prime \prime}$ black and white photographic print for an additional charge.

Photographs included in the original manuscript have been reproduced xerographically in this copy. Higher quality $6^{\prime \prime} \times 9^{\prime \prime}$ black and white photographic prints are available for any photographs or illustrations appearing in this copy for an additional charge. Contact UMI directly to order.

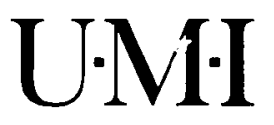

University Microfilms International

A Bell \& Howell Information Company 

Order Number 1337820

Special academic needs students in private elementary education in Santa Clara County

\author{
Lindsay, Kathleen Robinson, M.A.
}

San Jose State University, 1989 



\title{
SPECIAL ACADEMIC NEEDS STUDENTS \\ IN \\ PRIVATE ELEMENTARY EDUCATION \\ IN \\ SANTA CLARA COUNTY
}

\author{
A Thesis \\ Presented to \\ The Faculty of the School of Education \\ San Jose State University \\ In Partial Fulfillment \\ of the Requirements for the Degree \\ Master of Arts
}

Kathleen R. Lindsay

May, 1989 


\section{APPROVED FOR THE DIVISION OF SPECIAL EDUCATION AND REHABILITATIVE SERVICES}
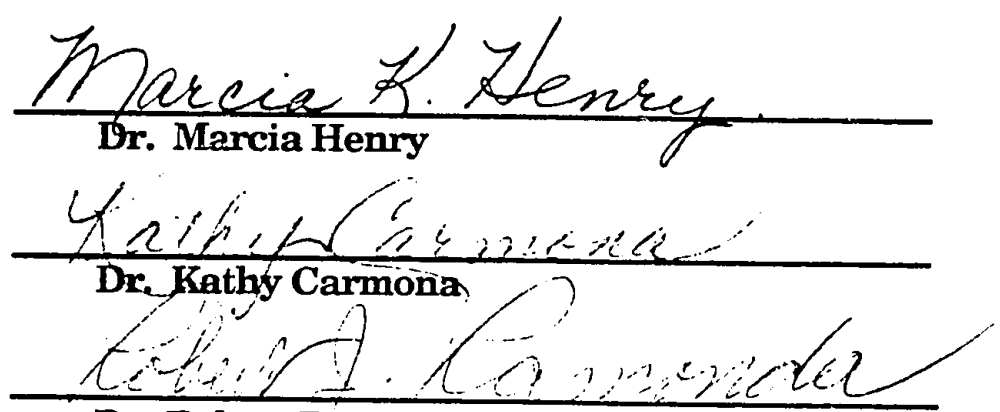

Dr. Robert Ramonda

\section{APPROVED FOR THE UNIVERSITY}

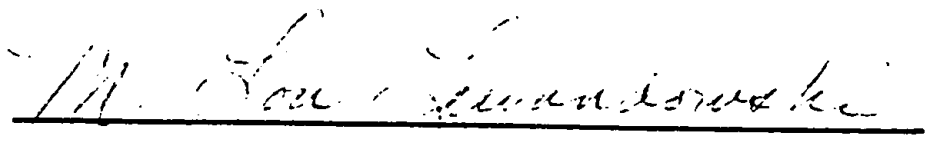




\section{ABSTRACT \\ SPECIAL ACADEMIC NEEDS STUDENTS IN \\ PRIVATE ELEMENTARY EDUCATION IN SANTA CLARA COUNTY by Kathleen R. Lindsay}

The purpose of this thesis is two-fold: (1) to describe the historical development of private education, including the relationship between government and the private school; and (2) to establish a base of information regarding the ways nonspecialized private elementary schools in Santa Clara County provide an appropriate education, as defined in the Education for All Handicapped Children Act of 1975 (P.L. 94-142), for students with special needs. Special needs students are those students who are learning disabled, culturally and linguistically different, or learning handicapped/gifted.

A two-step survey and interview procedure is used to determine how private schools are implementing P... 94-142. Research reveals that private elementary schools in Santa Clara County are responding to the special academic needs of students, particularly the mildly handicapped. The private school setting is unique in its ability to focus on student needs rather than on identification criteria. 


\section{TABLE OF CONTENTS}

\section{CHAPTER I - INTRODUCTION}

Background..................................................... 1

Problem Statement................................................. 2

Purpose and Significance....................................... 2

Research Questions

Private Education............................................. 3

Special Education in Private Schools........................... 4

Limitations, Delimitations, and Assumptions................... 4

Definition of Terms................................................. 5

CHAPTER II - LITERATURE REVIEW

Procedures.................................................... 12

Private Education in the United States.............................. 13

Definition of Private Education................................. 14

Development of Private Education in the U.S.

Pre-Revolutionary War.................................. 15

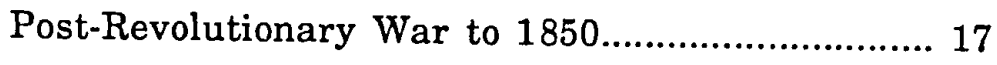

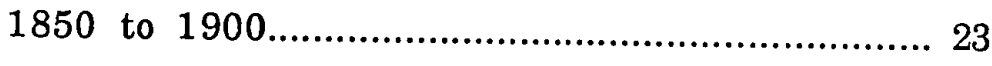

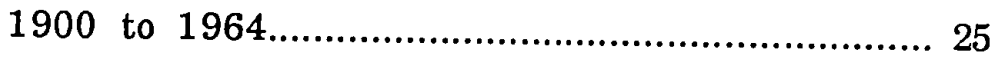

1965 to the Present........................................ 28

Legislation and Private Education.......................... 30

Litigation and Private Education............................ 31 
Development of Private Education in California:

An Overview ........................................................ 33

\section{CHAPTER III - METHODOLOGY}

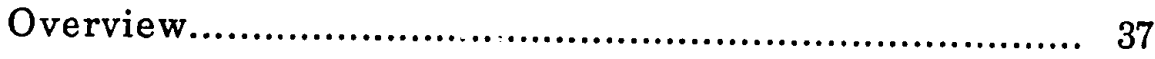

Private Education

Research Questions.............................................. 39

Research Method................................................... 39

Data Evaluation..................................................... 39

Special Education in Private Schools

Research Questions............................................ 40

Research Method.................................................... 40

Research Design: Survey........................................... 41

Population Criteria............................................ 41

Procedure................................................... 42

Analysis..................................................... 42

Research Design: Interview..................................... 42

Sample Criteria................................................... 44

Procedure......................................................... 44

Analysis....................................................... 44

CHAPTER IV - RESULTS AND DISCUSSION

Resuits

Data Presentation: Survey.......................................... 46

Data Presentation: Interview..................................... 50 


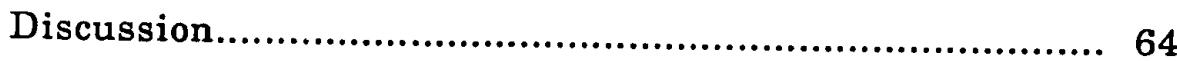

Conclusions.............................................................. 71

Recommendations for Further Research........................... 73

CHAPTER V - SUMMARY

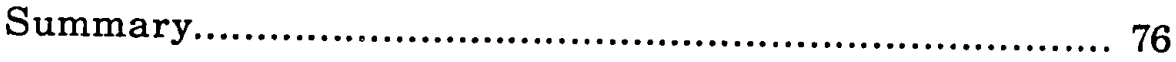

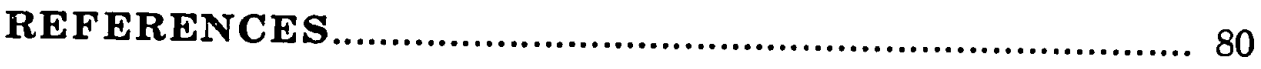

APPENDIX

A: Selected Legislation Affecting Private Education............. 86

B: Selected Litigation Affecting Private Education............... 90

C: Survey Protocol.......................................................... 93

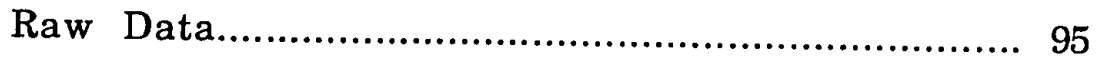

D: Interview Protocol.................................................. 97

Interview Data

Religious/Non-religious orientation...................... 101

Identification.............................................. 102

Referral.................................................... 103

Assessment................................................... 104

Placement................................................. 105

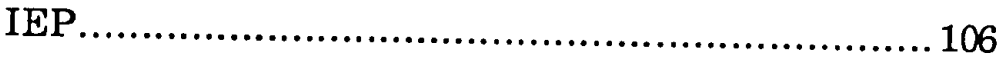

Parents' Rights............................................. 107

Services................................................... 108

Funding...................................................... 109

E: Research Agreement.............................................111

vi 


\section{CHAPTER I}

\section{INTRODUCTION}

\section{Background}

The details of the public school implementation of the Education for All Handicapped Children Act (P.L. 94-142) vary from district to district and state to state, but all state and district plans contain the same mandated elements: identification, screening, referral, multi-disciplinary assessment, planning, implementation, review, and the triennial assessment. Parents must be notified and included in all stages. A system of due process is also included in the federal and state plans in the event that a parental disagreement with district personnel cannot be resolved (Uavis, 1986).

Each district, special education services region or county office shall actively and systematically seek out all individuals with exceptional needs, ages

0 through 21 years, including children not enrolled in public school programs, who reside in the district or are under the jurisdiction of a special education services region or a county office (California Department of Education, 1989, p. 27, E. C. 30-56300). 
Since P.L. 94-142 covers all students with special needs, not just those ${ }^{1}$ actending public schools, it becomes just an "88\% solution" unless implementation also occurs in private schools where $12 \%$ of the students are enrolled (James \& Levin, 1988, p. 1). This study focuses on the current societal value of equal opportunity and equal access to an appropriate education for students with special academic needs who choose to attend nonpublic schools. The first part of the study traces private education's development in response to an ever-changing society in the United States. The second part of the study describes how students' special needs are met within today's regular private elementary classroom.

Problem Statement

How are private elementary schools (regular education) in Santa Clara County implementing the Education for All Handicapped Children Act of 1975, thereby ensuring an appropriate education for their students with special academic needs, specifically learning disabled (LD), learning handicapped/gifted, and culturally and linguistically different (CLD)?

\section{Purpose and Significance of the Study}

The purposes of this study are: (1) to describe the historical development of private education, including the rela'ionship between government and the private school; and (2) to establish a base of information regarding the ways private elementary schools in Santa Clara 
County provide an appropriate education for students with special needs, specifically learning disabled, culturally and linguistically different, and learning handicapped/gifted in the areas of identification of needs, referral, assessment, delivery of special services, and protection of parents' rights, as defined in P.L. 94-142.

This study is significant in bridging the knowledge gap concerning the current relationship between students with special academic needs in the private elementary school and their legislatively mandated rights. Literature describing the continuing issue of the relationship between private and public education is sparse. Some documentation does exist regarding the relationship of public schools to specialized private schools, but no information was found concerning how mildly handicapped students were functioning in the milieu of regular private education.

\section{Research Questions}

\section{Private Education}

Historically descripive research based on information obtained from extensive literature searches will be used to answer research questions pertaining to the development of private education: (1) What are the origins of private education in the United States? (2) What social movements affected private school development in the United States? (3) How have the private schools been affected by government legislation? (4) How have the 
private schools been affected by litigation? (5) What is the history of private education in California?

\section{Special Education in Private Schools}

A descriptive research approach utilizing information obtained rrom survey questionnaires and in-depth interviews will be used to determine how regular classes in private elementary schools in Santa Clara County accommodate students with special academic needs: (1) How many private elementary schools (regular education) in Santa Clara County accommodate students with special academic needs? (2) How are students with special academic needs identified in the private school? (3) Once a student with special academic needs is identified, what referral procedures are used in the private elementary school? (4) If the student is assessed within the private school, what assessment procedures are used? (5) If an individualizéa education plan is developed, who writes it? (6) Who is involved in making placement decisions? (7) How are special education services provided if the student chooses to remain in the private school? (8) Who funds special education services and assessment provided on site at the private school? (9) How are parents' rights safeguarded in the private school?

\section{Limitations, Delimitations, and Assumptions}

This particular study is limited to regular education private elementary schools having 50 or more students in grades K-6 as listed in the Private School Directory for Santa Clara County 1987-88, published by 
the Santa Clara County Office of Education. It is assumed that Santa Clara County is representative both in variety of implementation of state and federal law in the public school districts and in number and variety of private schools. Catholic schools have historically composed the largest segment of private education (Cooper, 1988); therefore, the development of private education focuses primarily on the development of Catholic private education. Since interpretation of various pieces of federal legislation has been left up to individual states or school districts, only general conclusions should be drawn from this study.

\section{Definition of Terms}

Appropriate education. An individualized education which emphasizes special education and related services to meet the unique needs of a student delivered in the least restrictive environment beneficial to that particular student.

Assessment. Multi-disciplinary individual testing and observation, using both formal and informal measures, background, health and family histories to determine the strengths and weaknesses of the student, academic as well as affective. Tests administered individually should be given in that student's primary language, and be as culture-free as possible. 
Bypass clause. A clause added to federal legislation to provide the mechanism for all states to have access to federal programs and federal monies in the cases where state constitutions might limit such access.

Chapter 1. A chapter of the Omnibus Reconciliation Act of 1981, Title V-Education Programs, Subtitle D-Elementary and Secondary Education Block Grant, Chapter 1-Financial Assistance to Meet Special Educational Needs of Disadvantaged Children (P.L. 97-35, 1981). Refer to Appendix A for details.

Chapter 2. A chapter of the Omnibus Reconciliation Act of 1981, Title V-Education Programs, Subtitle D-Elementary and Secondary Education Block Grant, Chapter 2-Consolidation of Federal Programs for Elementary and Secondary Education (P.L. 97-35, 1981). Refer to Appendix A for details.

CLD. An acronym for culturally and linguistically different, CLD stands for students who are from a different culture and speak a different language. CLD is a more inclusive descriptor of a student's background and possible educational needs than is the formerly used term "bilingual". The acronym CLDES (culturally and linguistically different exceptional student) is also used.

Common school. A school open to all children with curricular content similar to other common schools (Katznelson \& Weir, 1985). 
Education and Consolidation and Improvement Act (ECIA). ECIA is a subtitle of the Omnibus Budget Reconciliation Act of 1981, specifically, Subtitle D of Title V (P.L. 97-35, 1981).

Establishment clause. The First Amendment clause stating that "Congress shall make no law respecting an establishment of religion" (First Amendment of the Constitution of the United States).

Exercise clause. The First Amendment clause stating that Congress shall not prohibit the free exercise of religion.

Fourteenth Amendment. The Fourteenth Amendment of the United States Constitution states in part: "No state shall make or enforce any law which shall abridge the privileges of citizens of the United States." The Fourteenth Amendment is usually interpreted as extending to the states the same enjoinders pertaining to the powers of Congress (Benway, 1983).

Learning handicapped. The term is used synonymously with "learning disabled" within the context of this study. "Learning disabilities is a generic term that refers to a heterogeneous group of disorders manifested by significant difficulties in the acquisition and use of listening, speaking, reading, writing, reasoning or mathematical abilities" (definition by the National Joint Committee on Learning Disabilities cited by Hammill, Leigh, McNutt, \& Larsen, 1987, p. 109).

Learning handicapped/gifted. A child with "special intellectualprocessing problems that, nevertheless, maintains an extraordinarily high 
general intellectual potential" (Gallagher, 1988, p.110). The learning handicapped/gifted student usually manifests a severe discrepancy (skewed towards the high end) between achievement and potential when using an individual intelligence test; has coped with school fairly well (depending on compensation for the learning handicap); and demonstrates the thinking skiils associated with the gifted, if not in class, then when assessed on a one-to-one basis.

Least restrictive environment. The component of P.L. 94-142 stating that a handicapped student is to be educated with nonhandicapped students to the extent appropriate for that student.

Parents' rights. For the purposes of this study, those rights set forth in P.L. 94-142, including the right to inspect records; the right to advance written notification of referral, assessment, and other district service procedures; the rigint to inclusion in planning educational goals; the right to appeal decisions; and the right to be part of an advisory committee.

Private school. A school supported by private funds, usually a tuitionbased school having either a curriculum similar to public schools (regular education) or individualized and specialized to accommodate a particular handicap (special school); accountable to either a sectarian or nonsectarian advisory board, depending on the type of school.

Public school. A school supported with public funds, accountable to the public for curriculum as well as funds expended. 
Special education. "Modifications of, or additions to, school practices intended for the ordinary child--practices that are unique, uncommon, of unusual quality, and in particular in addition to the organization and instructional procedures used with the majority of children" (Kirk \& Gallagher, 1979, p. 12). 


\section{CHAPTER II}

\section{LITERATURE REVIEW}

Education for young children has been encouraged in the United States since the Revolutionary War. Following the war, new standards of expectations replaced traditional living patterns after the independence movement culminated in the creation of state governments. Organizations such as "academies of learning," previously open only to the elite, multiplied substantially, making education available to more people (Brown, 1976, p. 89).

According to Jorgenson (1987), the church-state school was as much an ancestor of the present-day parochial school as of the modern public school. School curriculum, organization, and composition were determined by the complex interrelationships of emerging government, social tenor, sectarian influences, and nativism, a philosophy of opposition towards immigrants and acculturation.

Education for children with visible handicaps (blind, deaf, or physically impaired) received limited assistance from many state governments after the turn of the century; classes for the mentally retarded or behaviorally disordered were provided in some states. A healthier economy following World War II allowed more financial support of 
specialized classes for the handicapped; women, replaced in the work force by returning soldiers, re-oriented their energies towards education and advocacy for their children. As characterized by Heward and Orlansky (1980), a "civil rights movement for the handicapped" (p. 11) during the $1950 \mathrm{~s}$ and $1960 \mathrm{~s}$ spurred legislation guaranteeing appropriate educational services for exceptional children. The landmark court case of Brown $v$. State Board of Education of Topeka (1954) established equal opportunity for all children to receive an education.

Continuing parent advocacy resulted in additional court decisions further establishing and clarifying children's educational rights. Parent advocates combined with increasingly sensitive legislators to develop legislation that included the Elementary and Secondary Education Act in 1965 and its various Amendments which provided funds to states and local districts to develop programs for disadvantaged and handicapped children (Heward \& Orlansky, 1980). Up until this point, monies had only been allocated for training professionals to meet the perceived needs at the time.

The Learning Disabilities Act, passed in 1969, defined learning disabilities and provided programming monies for that population. With the passage of P.L. 91-230 in 1970, handicapped and exceptional children were recognized as a single population with special needs (Heward \& Orlansky, 1980). Previous court cases, parent advocacy, and prior legislation culminated in P.L. 94-142, the Education for All Handicapped 
Children Act of 1975, the foundation for today's special education practices (Davis, 1986).

Important concepts of P.L. 94-142 included: (1) the assurance of the availability of a free and appropriate education for all handicapped people under the age of 21 regardless of the type or severity of their disability; (2) multi-disciplinary assessment to be conducted in the student's own language; (3) special education and related services to be provided in the least restrictive environment appropriate to that student; (4) an individualized education plan to meet each student's unique needs; (5) provision for parental involvement in a child's education; (6) protection of parents' rights through written notification; and (7) due process.

Before determining how private elementary schools (regular education) were providing an appropriate education for students with special needs, several literature searches were conducted to: (1) determine any prior research concerning special needs students in private schools; (2) trace the development of private education in the United States; (3) trace the development of private education in California; and (4) identify major legislation and court decisions affecting private schools.

\section{Pmcedures}

Literature searches utilized the resources of libraries at San Jose State University (SJSU), including the computerized Educational Resources Information Center (ERIC), Stanford University, and the Santa Clara 
County Library system, to gather background information and locate previous research. The Government Documents section at SJSU's Clark Library yielded current information on the education codes; the Media Center contained ERIC documents on microfiche. Journal articles were located in both SJSU's Clark Library and Stanford's Cubberly Hall Education Library since the two universities subscribe to different periodicals. The Center for Educational Research at Stanford (CERAS) was also a source for current research information. The California History Center at DeAnza College, Cupertino, a repository for historical information about California's development, was an invaluable resource in determining development patterns of private education in California.

\section{Private Education in the United States}

Research about special needs students in specialized private schools appeared readily available. Previous studies about private schools focused on tuition credits, high schools, school effectiveness, or school systems in other countries. Chambers (1988) referred to a $1981 / 82$ survey conducted within the greater San Francisco Bay Area under the auspices of Stanford University's Institute for Research on Educational Finance and Governance. The main focus of Stanford's research, funded by a grant from the National Institute of Education, was "to ascertain how the two sets of schools [public and private] are similar and differ and what each can learn from the other" (James \& Levin, 1988, p. vii). 
No prior research was found concerning special needs students in regular elementary private schools. Information might be forthcoming, however, from a task force sponsored jointly by the Council of Exceptional Children (CEC) and the National Association of Private Schools for Exceptional Children (NAPSEC). In 1985 the CEC-NAPSEC Task Force, recognizing the ambiguity of the relationship between public and private schools, convened a Task Force to "develop guidelines for effective cooperation between public and private sectors in meeting legal and professional responsibilities for the education of children with disabilities" (Riggen, et al., 1987, p. 3). The Task Force recommended that CEC and NAPSEC develop a model state level inter-agency agreement for use by public and private schools.

\section{Definition of Private Education}

The modern definition of private education is still ambiguous after three centuries of existence in the United States. The term private school can refer to either a parochial school or a nonpublic school. Nonpublic schools are operated as either profit-making or non-profit institutions. Private and public have previously been defined as sectarian and secular, depending on the school's curriculum. The differences, though ambiguous at times, have been even more nebulous. John Whitehead (cited in Levy, 1986) stated that a "clear distinction between 'private' and 'public' did not exist in the century between 1776 and 1876" (p. 171). 
One church-sponsored school titled itself the New York Protestant Episcopal Public School after 1826. A Congregationalist secondary school was styled the Hartford (Connecticut) Public High School as late as 1871. The "public" schools of Washington and Georgetown, D.C., were under essentially private control until the middle of the nineteenth century (Jorgenson, 1987, p. 5).

As late as 1881 a Minnesota court could issue the opinion that a Catholic parochial school, operated not for profit and open to all children, "is, in the legal sense, not only a charity, but one wholly and entirely of public nature, and therefore, a public one" (County of Hennepin v. Grace, [27 Minn.] 506, cited in Jorgenson, 1987, p. 7).

\section{Development of Private Education in the United States}

Pre-Revolutionary War. The history of private education in the United States is also a history of the founding and growth of the colonies, of compulsory education, and of the roots of public education. Puritan settlers in the Massachusetts Bay Colony passed the first major school law in 1647, "The Old Deluder Satan Act," requiring each town to establish and maintain a school in order to keep the children busy, since idle hands were regarded as tools for the Devil (Pulliam, 1982). The Bible became the initial 
reader since Puritans were concerned that all their members should learn to read the Bible as a further protection from Satan's encroachment. In addition to a strong desire to ward off evil through education, the New England colonists, being primarily from English-speaking countries, also brought with them an emphasis on the English language.

Colonists from Massachusetts, New Hampshire, Connecticut, and Rhode Island (the New England Colonies), while in agreement that it was their Christian duty to educate their children in both religious principles and parliamentary rule, could not agree on the religious principles to be taught in school. The various denominations, therefore, conducted and controlled their own schools. Schools were established to propagate the Gospel and control new generations. New England colonies passed laws requiring children to be educated, but left the details of implementation up to the individual communities. The selectmen of a town, the General Court, or the ministers constituted ultimate educational authority. The Southern colonists of Maryland, Virginia, and the Carolinas, lacking the Puritan zeal for reading, exhibited a more laissez-faire attitude towards education. Social equality did not develop in this atmosphere of acceptance of one's station in life; lack of public interest in schooling was also evident. Educational decisions were made by the Archbishop of Canterbury or the Bishop of London, responsible for licensing teachers. Diversity and parochialism were the hallmarks of the Middle Colonies 
of Delaware, New Jersey, New York, and Pennsylvania, with an immigrant population not just from England, but also from Holland, Germany, Sweden, Wales, and Scotland. The Middle colonies also became a haven for other colonists escaping from religious persecution. A great variety of schools developed: common schools where each family paid as they could; private venture schools with specialized, practical subjects; academies featuring only vocational education; Latin grammar schools that were college preparatory schools exclusively for men; and individual denominational school systems. Quakers provided the first teacher education in America--an apprenticeship. The only school laws at this time concerned the licensing of teachers.

During the Revolutionary War, men's energies turned towards protecting their homes and ideals and away from education. Illiteracy increased with the closing of rural schools, the lack of books from England, and the burning of schools and libraries. Many talented Loyalist teachers returned to England. "The Revolvition dealt harsh blows to intellectual life in America, but it also provided the seeds for intellectual activity independent of Europe" (Pulliam, 1982, p. 51). Brown (1976) voiced a similar opinion that "the independence movement, the war, and the creation of state governments were great raisers of expectations" (p. 88).

Post-Revolutionary War to 1850. The latter years of the eighteenth century and first decades of the nineteenth century were marked by 
expanding ideas and savoring new freedoms. Awareness of responsibility to others in the country and the world was brought forcefully home during the Spanish-American War. Members of social movements experimented with new ideas while other people remained with the old ways. Economic reality became a driving force as the United States moved from an agrarian to an industrialized nation.

The withdrawal of English dollars following the Revolution weakened the sectarian schools, but the rising tide of democracy resulted in growth for the academy and town schools. Monetary school support was considered at the Constitutional Convention and the seeds of the perennial issues of governmental control and support for education (public or private) were planted. The confusion of yesterday, illustrated by two differing accounts of the Convention, is still extant:

It was the prevailing view of the founding fathers that while knowledge was the best guardian of liberty, education did not belong in federal hands. James Madison wanted a general tax for schools, and Samuel Knox argued that private schools were subversive in a republic, but such reasoning did not convince the Constitutional Convention. The Constitution, therefore, contains no reference to education (Pulliam, 1982, p. 56). 
In contrast, Stickney and Marcus (1984) reported that James Madison's journal of the Constitutional Convention, unpublished before 1840, contained indications that the creators of the Constitution understood that education would be included under Article 1, Section 8, (the Welfare Clause). The Welfare Clause empowers Congress to pay the country's debts and provide for its defense and general welfare. Stickney and Marcus further stated that Alexander Hamilton's account agreed with Madison's journal.

Jorgenson (1987) related that schools were again built and staffed during reconstruction following the revolution. The most educated citizens, the clergy, were relied upon to provide educational leadership as well as instruction in reading and writing. By the 1830 s there was a choice between public schools having a Protestant-influenced curriculum and nonpublic schools, usually parochial schools, having a Catholic-influenced curriculum.

Horace Mann, a Unitarian, believed that religious instruction was an important part of common school work, but should be non-sectarian. However,

Horace Mann never became an enthusiastic advocate of compulsory school attendance laws. He wanted all children to be in school...yet he was reluctant to sacrifice what he held...to be a principle of American democracy, 
the right of the parent to determine what his child should do (Ensign, 1969, p. 48).

"The education of children had always been within the ambit of churchly and ministerial activity, and supporters of the Common School Movement [including Horace Mann] obviously assumed that this tradition should continue" (Jorgenson, 1987, p. 32). The Common School Movement, 1830 to 1860 , was a movement of expansion and improvement of education at the elementary level. An underlying theme of the movement, according to Jorgenson, was that public education was an agent of moral redemption for the soul achieved through non-sectarian means. Goals of the Common School Movement included: (1) schooling for all white children at public expense; (2) encouraging or requiring school attendance; (3) creating training programs for teachers; and (4) establishing state control over goals one through three.

Common School supporters belonged primarily to the Whig party. Whigs favored an active role in government and direct economic activity. The Whig philosophy of respesting property, working hard, and accepting one's lot in life, included the belief that education was the basic instrument for achieving control and social progress. Whigs, while not opposed to individual freedom, believed in subordinating that freedom for social good and econornic gain. In contrast, the Jacksonian Democratic philosophy regarded freedom for the individual as equal to the greatest societal improvement. Both philosophies contributed to the current dualistic 
educational conflict of individual freedom versus greatest societal good as seen in the struggle between special education, responding to the individual, and regular education, responding to society as a whole.

Prior to 1840, Catholic leaders had been sympathetic to the Common School Movement. Lowell, Massachusetts, from 1835 to 1840, was the site of a Protestant-Catholic experiment in cooperation when two Catholic schools wese incorporated into the public system: the school committee appointed teachers and selected books and curricula that, by prior arrangement, would not be offensive to Catholics. Other parochial-public attempts at cooperation were found in Poughkeepsie, New York, (1873-1898) and in Pittsburgh, Pennsylvania, in 1887.

Overseeing education was the right of the states reserved under provisions of the Tenth Amendment. Congress made clear their intention that each state provide for the education of its citizens by passing the Ohio Enabling Act of 1802: each proposed state was required to have an education system written into its constitution, and to set aside land to be used for the support of education.

The 1840 s was a decade of controversy over both state aid to parochial schools and religion in public school. Demographics changed with the incoming waves of immigrants. The word nativism was coined in 1840 to describe the anti-foreign fervor of the 1830s and 1840s. Anti-Catholicism, the oldest and strongest form of nativism, was intensified by the increasing 
numbers of Catholic immigrants. Nativistic sentiment resulted in stiff naturalization laws and in the exclusion of foreigners and Catholics from public office; a climate conducive to the growth of the Know-Nothings was created. The name Know-Nothing was attached to this secretive group when efforts to learn about their leadership were met with the response by members that they knew nothing.akout their leaders.

The Know-Nothing-Movement was a "culmination of antebellum nativism" that claimed as its goal a "homogeneous Protestant culture" (Jorgenson, 1987, p. 70). Local societies in New York formed the American Republican Party in 1843, becoming a national organization in 1845 . The Order of United Americans and the Order of the Star Spangled Banner were also part of the Know-Nothing Movement.

The Know-Nothings failed to achieve their anti-foreign and antiCatholic goals on a national level, but on a state level the "Know-Nothing campaigns produced a major turning point in the development of American education...[by] firmly establishing the precedent that non-public schools are ineligible to receive public financial support" (Jorgenson, 1987, p. 72). Know-Nothing leaders also aligned with Protestant officials to legislate that just the King James version of the Bible was read in public schools.

Catholic reaction to Protestant entrenchment in the public schools, vis a vis state monies and reading the King James Bible, resulted in the First 
Plenary Council of Baltimore (1852), a convocation of the nation's bishops, endorsing rather than merely encouraging the concept of parish schools. Catholics viewed parochial schools as essential because of the Bible controversies and the increasing secularism in schools which was "as objectionable as the Protestant orientation it was gradually replacing" (Jorgenson, 1987, p. 84). In 1884 the Third Plenary Council stated that "Catholics do not oppose the public school. They merely consider it inadequate for the education of Catholic children because of its admittedly necessary omission of religious training" (p. 145).

1850 to 1900 . Educational history in the last half of the nineteenth century was affected by the Civil War, new waves of immigrants, compulsory education laws, and a physically expanding country. During the War Between the States men's energies were once again diverted from education. Most southern schools closed while northern schools continued in session. Previous immigrants had come from northwestern Europe and Scandinavia; following the Civil War, the immigrants came from other countries as well. These immigrants from Spain, Russia, Austria, Hungary, and Italy, had experienced the dual educational systems of Europe, educating only the elite, and wanted a free public education for everyone. The political climate was ripe for this notion: not only were there immigrants, but also newly freed slaves to be educated in the ways of "the American dream...a homogeneous culture" (Jorgenson, 1987, p. 147). 
Ensign (1969) reported that compulsory education laws, under state (1r. local jurisdiction, were written and re-written reflecting the changes in the economy and the perceived need for an educated electorate. Initially, the burden to comply with school attendance requirements was delegated to the family. Later compulsory education laws placed the compliance burden on the state and held factories or other workplaces accountable for misdemeanors. These later laws were more successful. The end result of compulsory education law is the student work permit currently in use.

Polarization of American society during the 1880 s and 1890 s was a result of slum deterioration, corruption in municipal government, and the beginning of the labor movement; economic dependency shifted from agriculture to industrialization. Immigrants became the scapegoat and nativism, historically present during uncertain times, again raised its head.

Settlement houses such as Hull House in Chicago and Andover House in Boston, based on an 1880s English response to the "appalling conditions of industrialism" (Cremin, 1964, p. 59), were the United States' attempts to humanize industrial civilization. Education within the settlements emerged as the primary tool to decrease joblessness and combat illiteracy, two of the most debilitating ills of the settlement residents. The panoply of educational offerings grew in response to residents' needs: kindergartens and day nurseries for working mothers; English classes for immigrants; 
dressmaking and cooking classes for home-bound residents. "The settlement theme of regeneration was patent...Americanization came to be viewed as a venture in social education, immigrant education, a cooperative effort to improve the quality of neighborhood life" (p. 75).

1900 to 1964 . The twentieth century was a time for experimentation, clarification of loyalties, and a growing interest in the social sciences. An increased awareness of human dignity and worth and a willingness to look at the inequities in society were milestones of the times.

The view that education integrated with politics would result in the realization of the promise of American life spawned the Progressive Movement which, in turn, fathered progressive education. Progressive private educational institutions played a prominent part in actualizing pedagogical theories: Marietta P. Johnson's Organic School in Fairhope, Alabama, nurtured and educated the whole child; John Dewey's Laboratory School in Chicago, Illinois, tested Dewey's own theories of individual development. Private school representatives were members of the Progressive School Association, a vehicle for information exchange.

The epitome of nativism and religious prejudice was the Oregon initiative passed in 1922. This initiative required students eight through sixteen years of age to attend public schools, considered the primary defense against cultural pluralism during World War I. Jorgenson (1987) cited the Perils of Pluralism in which Professor Tyack speculated that the 
Oregon initiative was a "test case for compulsory public education" (p. 207) by the Ku Klux Klan organization to see if a majority of citizens would support a state monopoly of education. The vote on the initiative was close: 115,506 to 103,685 . No previous law in any state had required attendance only in public schools, although Nebraska had come within one vote of adopting such a law.

The results were challenged in court by two non-public groups: Sisters of the Holy Names of Jesus and Mary, who maintained several schools in Oregon, and Hill Military Academy. The court case was commonly referred to as Pierce versus the Sisters. During the "Pierce Battle" (Jorgenson, 1987), a former U.S. commissioner of education, Philander P. Claxton, declared "[that] the public school system had been the salvation of democracy, but that the private schools have been the salvation of the public schools" keeping them from becoming "autocratic and arbitrary" (p. 215).

In 1925 the Supreme Court ruled in favor of the Sisters, setting the limits of state involvement in private education (see Appendix B). After the Pierce decision legitimizing nonpublic education, private schools continued to multiply. The number of Catholic elementary schools grew from 3,811 in 1900 to 10,879 in 1964, the highest enrollment Catholic schools have had (Cooper, 1988).

The Great Depression of the 1930s ended, according to Pulliam (1982), when the United States entered World War II during President Roosevelt's administration. Economic concerns promp ed New Deal Acts, such as the 
Civilian Conservation Corps, the National Youth Administration, and the distribution of surplus foods to the schools. The increased paternal intrusion of the federal government was felt when loans to students encouraged study in the subjects of critical wartime need; during World War I training had been given on campus.

The Depression resulted in renewed concern for the individual's dignity, worth, and economic rights. The National Education Association in 1949 captured these ideals in their Purposes of Education in American Democracy: I. The Objectives of Self-realization; II. The Objectives of Human Relationship; III. The Objectives of Economic Efficiency; IV. The Objectives of Civic Responsibility. John Dewey prefaced the statement of aims by stating that education is the effort to integrate social skills with human behavior (Stone \& Schneider, 1971).

The decade of the fifties saw an emphasis on basic curricular subjects as well as increased educational legislative activity by the federal government in reaction to the Cold War and Sputnik. "The success of the Soviet Union in launching Sputnik in 1957 shifted [education's] emphasis from life adjustment to excellence and led to the National Defense Education Act" (Pulliam, 1982, p. 164).

A new era for litigation commenced in the fifties when "the Supreme Court began to view consititutional rights as national, rather than regional, in nature" (Stickney \& Marcus, 1984, p. 129). "The Court decided that 
schools had to answer to a higher standard than that set by the local officials" when the landmark opinion Brown v. State Board of Education of Topeka was rendered in 1954: "separate educational facilities are inherently unequal.....Brown opened the schools to federal scrutiny in order to guarantee that the 'equal protection' and 'due process' clauses of the Constitution do not stop at the schoolhouse door" (p. 129).

Social unrest, specifically against racial inequality and injustice, resulted in the Civil Rights Act of 1964. The Civil Rights Act not only affected education, but empowered a people: "black children now view their rights to access to facilities and services as being as American as apple pie" (Stickney \& Marcus, 1984, p. 31 ).

1965 to the present. The decade between 1965 and 1975 was spent creating legislation reme fying the perceived inequalities in the educational and social system. Passing the Civil Rights Act of 1964 (Davis, 1986) was like discovering the tip of the iceberg: its future impact was unfathomable. American society struggled with the demands for a quality education from a diverse citizenry. Blacks have only recently felt the reality of an equal education in most parts of the United States. A similar civil rights action for the handicapped was taken in 1975 with the passage of the Education for All Handicapped Children Act (Lerner, 1989).

The private school sector, according to James and Levin (1988), has also changed. American private schools are as diverse as the nation itself. 
Over the decades the proportion of children attending private schools versus those attending public schools has remained constant, even though the numbers have shifted within the nonpublic school population. Catholic school enrollments declined from the 1960s until the early 1980s, while other nonpublic school enrollments rose. The 1985 Lines' report contains an overview of how each state regulates private schools, requirements for teachers, curriculum, student testing, and non-discrimination. For instance, California specifies that subjects taught in the private school would be the same as those taught in public school; prohibition of race discrimination is limited to schools receiving state aid; and instruction is required to be in English, with exceptions made for pupils who are not proficient in English.

Private schools are particularly sensitive to the nuances of government. In 1986, Hirschoff posed these relevant questions: "(1) To what extent should government encourage or discourage the choice of private schooling, that is, what balance between public and private schooling should government try to achieve? (2) What differences between private and public schooling should government promote or prohibit?" (p. 33). Increased legislation and litigation have attempted to define and to refine the federal government's role in both private educational policy and in private educational financing. 


\section{Legislation and Private Education}

The primary legal tools for regulating private schools are compulsory education laws. Lines (1985) agreed with the right to ask educators to prepare children for the new demands made by an information society at the same time acknowledging that requiring the same program for all children has its limitations. Using compulsory education laws to regain the U.S. position as a leader in technology is too great a threat to individual liberties. Lines recommended that school reforms could be achieved through creating such an enticing public education program that compulsory education requirements could be kept to a minimum. "Compulsory education laws typically are criminal laws, setting minimum requirements to protect children from parental neglect or from their own thoughtlessness" (p. 4).

Compulsory attendance laws, viewed as either homogenizing the citizenry or as anti-parochial legislation in disguise, were addressed by all states. According to Jorgenson (1987), Wisconsin, influenced by the concentration of Germans, passed the Bennett Law which was supposedly an act concerned with children's employment, but in actuality was more concerned with the teaching of all school subjects in English. Illinois' Edwards law, passed in 1883, but repealed in 1893, also specified subjects that were to be taught in English. The replacement statute merely required attendance at either a public or nonpublic school. 
How far can the state venture into the arena of regulating private schools? "The state's concern must be limited to the minimum requirements needed to assure its interests--the growth of the child into a self-sufficient citizen" (Lines, 1983, p. 214). Most states require private schools to submit information needed to verify student attendance; most states prohibit racial discrimination; many, but not all, states are involved in the regulation of health and safety standards; states may also influence the prevention of child abuse. Lines suggested that because of the state's interest in consumer protection, it could require private schools to accurately inform the public of the qualifications of the schools and teachers. An appendix is attached to Lines' 1983 report giving requirements for compulsory school attendance on a state-by-state basis.

\section{Litigation and Private Education}

Examination of the relationship between private education and the federal government included examination of the relationship with the judicial branch as well as the legislative branch of the government. Supreme Court rulings are now as powerful as mandates emerging from the enactment of legislative statutes. Congress has the power under the Constitution (Article III, Section 2, Paragraph 2) to limit the Supreme Court's jurisdiction to those areas specified as appellate jurisdiction, ruling only in previously specified areas (Stickney \& Marcus, 1984). The federal courts "were created under the authority granted to Congress by the Constitution; they were not mandated by the law of the land" (p. 143). 
McGee (1987) posited that the emphasis in litigation has changed. "Early-day legal action usually sought to protect the rights of some select group from unconstitutional infringement of their rights" (p. 3). The courts now appear to be making decisions on a case-by-case basis, "paying closer attention to specific standards and requirements...relative to compulsory attendance cases" (p. 9).

According to Benway (1983), James Madison and Thomas Jefferson, as chief architects of the Constitution and Bill of Rights, are responsible for the church-state separation as it exists today. This historical separation has led to the current court challenge of striking a balance between the establishment clauses and the free exercise clauses of the First Amendment, specifically where the use of public funds for the support of private and parochial schools is concerned.

The Fourteenth Amendment extends the free exercise clause of the First Amendment to the states and also makes applicable to the states the ban on the establishment of religion. The government must assume the position of neutrality in regard to religion. The government may not encourage or inhibit religion, nor can government avoid the establishment of religion to the degree it prevents the free exercise of religion (p. 201). Benway further reported that the Supreme Court has consistently 
ruled that the way public assistance is provided through sectarian schools is not as important as the verification that assistance did indeed flow to purely secular educational activities.

\section{Development of Private Education in California: An Overview}

The first educational attempts in California were made by the missionaries in the eighteenth century. Twenty-one missions, an integral part of the educational process, were founded between the years 1794 and 1800 (Hendrick, 1980). The early 1840s saw an increase in immigrants from the east, bringing with them their Yankee values emphasizing education, mass literacy, civility, and "moral behavior as interpreted by the Protestant faith. Private control had already become identified with the Catholic Irish and Germans who wanted to protect themselves from Protestant influences" (p. 6).

The first school board was elected in San Francisco in 1848. Schools were financed through both public funds and tuition. Many people, including schoolmasters, left when gold was discovered. California's constitution, drafted in 1849, included mention of a superintendent of public schools: only four other states had a superintendent at that time. The constitution set the framework for a common school system operated by local townships under the supervision of the elected superintendent of public instruction.

Acquiring literacy was the focus of education, regardless of whether 
private or public dollars were used. The picture changed several times over the next few years: California's first state school law, passed in 1851, provided that any school, "if found to be efficiently conducted and to offer the branches of education provided in the district school, 'shall be allowed a compensation from the Public School Fund...in the same manner as provided for District schools in the Act"' (Judge Marvin and the Founding of the California Public School System, cited in Jorgenson, 1987, p. 104). All teachers in schools receiving public funds, even religious, were certificated by county commissions of education. A close relationship between schools and churches existed during the early statehood years.

The 1852 legislature, lobbied by John Swett, rescinded the provision regarding public monies distributed to private schools. The new wording stated that money would go cnly to schools "free from denominational and sectarian bias" (Jorgenson, 1987, p. 105). Such a reversal was possibly due to rapidly changing population patterns with the discovery of gold. Incoming immigrants, primarily Protestant, began inveighing antiCatholic sentiments. The law was again amended in 1853 to divide the money among all qualified schools. The Know-Nothings now raised their heads and in 1855 the Ashley Act sounded the death knell for state aid to sectarian schools in California.

An Act to Provide for a System of Common Schools provided texts and supplies to assure all students except non-whites a free education. 
Hendrick (1980) dated the passage of the Act as 1866 under the superintendency of John Swett; Goda (1967) reported May 3, 1852. Goda continued, "Catholics in California, it may be added, could be said to have weakened their [educational funding] position by making many of the same arguments against the Chinese that others were making against the Catholics" (p. 168).

California was one of the first states to pass an enforceable compulsory education law. An 1874 Act to Enforce the Educational Rights of Children required school attendance for all students 8 through 14 years of age. Penalties for non-compliance were included in the Act (Hendrick, 1980).

During the second California constitutional convention, it was decided to control educational matters locally: the state legislature would pass no laws dealing with the management of local schools; county superintendents could certify teachers; and local boards could adopt textbooks. However, a dual system of teacher certification emerged: the state prescribed requirements for certification and issued credentials for teaching; the county issued the certificate if requirements were met. This system remains in effect.

Racial segregation attempts reflect California's changing population. Though legal segregation of blacks ended in 1880, the Chinese Exclusion Act was passed in 1882. An attempt to segregate Japanese children in San 
Francisco's public schools in 1906 was followed by the Japanese and Korean Exclusion Act of 1924 (Hendrick, 1980).

The public, generally supportive of education, became critical in the 1960s and 1970s claiming that education had lost its vitality. Laws were passed by the state legislature in an attempt to revive education's vigor. The 1961 Fisher Act required teachers to have an academic major and a fifth year of college work. The 1970 Ryan Act created the Commission for Teacher Preparation and Licensing and emphasized a more experiential approach to teacher education. The 1971 Stull Bill mandated that teachers "define what they expected their students to learn" (Hendrick, 1980, p. 47).

The Education Commission of the States (ECS) was designated in 1984 by the National Institute of Education's Educational Policy and Organization Program to survey all state and territorial statutes relating to private education. A summary of California's responses revealed that textbooks could not be loaned to nonpublic schools, but audiovisual materials may be supplied to nonpublic elementary schools for a fair rental value. Testing services were available under the National Defense Education Act, but no provision was made for counseling. "Cooperation with private schools in the state's special education program is expressly restricted to 'nonpublic, nonsectarian schools'" (California Education Code section 56001 [k], cited in ECS, 1984, Master Table VI, p. 6). 


\section{CHAPTER III}

\section{METHODOLOGY}

\section{Overview}

Public school requirements for providing an appropriate education for learning handicapped or bilingual students have been delineated in several pieces of legislation, among which are the 1975 Education for All Handicapped Children Act (P.L. 94-142), Section 504 of the Rehabilitation Act of 1973 (Davis, 1986), and Title VII of the Elementary and Secondary Education Act of 1968, also known as the Bilingual Education Act (Baca \& Cervantes, 1984). The Education Consolidation and Improvement Act of 1981 (P.L. 97-35, Sec. 551) consolidated many federal programs and created block or categorical grants in an attempt to return more control to the local governments. Numerous pieces of litigation have resulted in refined and clarified definitions and more clearly specified services for students with special needs in the public schools.

The purposes of this study were: (1) to describe the historical development of private education, including the relationship between government and the private school; and (2) to establish a base of information regarding the ways private elementary schools in Santa Clara County provide an appropriate education for students with special needs, 
specifically learning disabled, culturally and linguistically different and learning handicapped/gifted in the areas of identification of needs, referral, assessment, delivery of special services, and safeguarding parents' rights, as defined in P.L. 94-142. Chapter II described the development of private education in the United States and traced the historical relationship between government and the private school. Chapter III will describe the research methods used to establish a base of information regarding the ways private elementary schools in Santa Clara County provide an appropriate education, as defined in P.L. 94-142. Chapter IV will report the results of the research conducted in Santa Clara County.

A two-step survey and interview procedure was used to gather information from private schools in Santa Clara County meeting the research criteria. Raw data were tabulated and analyzed. The following sections detail research design, population sample, data collection procedures, and data analysis.

The survey form and the questionnaire were field-tested by private school colleagues who were not involved in the research, a librarian, an engineer, and a high-school senior. Both instruments were checked for content validity, clarity, and ease of responding. Reliability was not measured. 


\section{Private Education}

\section{Research Questions}

Five research questions about the development of private education in the United States were explored during extensive literature searches:

(1) What are the origins of private education in the United States? (2) What social movements affected private school development in the United States?

(3) How have the private schools been affected by government legislation?

(4) How have the private schools been affected by litigation? (5) What is the history of private education in California?

\section{Research Method}

The first part of the study focused primarily on the past. A descriptive historical method of research using both primary and secondary information sources was used to chronologically trace the development of private education in the United States and in California.

\section{Data Evaluation}

An informal cross-checking of sources was done where possible to eliminate false information. When discrepancies could not be resolved, the differing opinions were noted. Because data were primarily based on secondary sources, no generalizations should be drawn from the first part of the research, or Appendices A or B. 


\section{Special Education in Private Schools in Santa Clara County}

\section{Research Questions}

Nine research questions probed how students with special needs are accommodated in private elementary schools: (1) How many private elementary schools (regular education) in Santa Clara County accommodate students with special academic needs? (2) How are students with special academic needs identified in the private school? (3) Once a student with special academic needs is identified, what referral procedures are used? (4) If the student is assessed within the private school, what assessment procedures are used? (5) If an individualized education plan is developed, who is involved in developing it? (6) Who is involved in making placement decisions? (7) How are special education services provided if the student chooses to remain in the private school? (8) Who funds special education services provided on site at the private school? (9) How are parents' rights safeguarded in the private school?

\section{Research Method}

The second part of the study focused on how special needs students are accommodated in private elementary schools today. A descriptive research approach was employed utilizing a two-step survey and interview process to gather information describing services to special needs students in private elementary schools in Santa Clara County. Results of the survey were used to answer demographic research questions about enrollment sizes and the 
religious orientation of the schools in the study. Results of the interviews were used to answer the other research questions.

\section{Research Design:Suryey}

The survey (see Appendix C), designed to be answered quickly, was composed of six questions, including trigger questions (questions three through six). Trigger questions are those questions prompting a response, in this case a follow-up interview. Questions 1, 3 (b), and 5 required forced choice answers; questions 4 and 3 (a) requested a "Yes/No" response; question 6 was open-ended, allowing for individualization of response.

Question content: (1) religious or non-religious orientation; (2) school census for 1988-89; (3) number and types of special needs students enrolled; (4) use of an individualized educational plan (IEP); (5) referral procedures; and (6) contact with public school district. Space was left to allow for any comments that might have been generated by the survey. This space was also used by some respondents to decline participation in the interview process.

Population criteria. A school had to meet all the criteria to be included in the survey portion of the study:

Criterion 1 - the school must be private;

Criterion 2 - the school must enroll elementary students;

Criterion 3 - the school must have fifty or more students enrolled, as listed in the 1987-88 Private School Directory, Santa Clara County, 
published by the Santa Clara County Office of Education;

Criterion 4 - the school must have a regular curriculum, as opposed to specialized curriculum, as determined by the listing in the Private School Directory.

Procedure. Surveys (see Appendix C for copy), each with attached cover letter approved by the San Jose State University Human Subjects Committee, and a stamped, self-addressed return envelope, were mailed to all schools meeting the survey research criteria. School addresses and names of principals were obtained from the Private School Directory published yearly by the Santa Clara County Office of Education.

Analysis. Responses to question 6 (open-ended) and additional responses received in the Comments section were categorized; all responses were then tallied and tabulated. Descriptive analysis, as defined by Best and Kahn (1986), though limiting generalization to the population surveyed, was considered appropriate for analyzing the data received. Data analysis included frequency distributions, and computation of percentiles. Analysis of survey results is presented both narratively and graphically as appropriate for the topic.

\section{Research Design:Interview}

The on-site interviews with school administrators provided the opportunities for an individualized, in-depth focus on a school's procedures of identification, referral, and assessment; placement options; IEP or informal plan writing; and parental involvement. Interviews allowed for 
follow-up research on unexpected responses or information gained either during the interview or the survey process. The two-way communication afforded by the interview situation was a more comfortable way to discuss the potentially sensitive topics of school philosophy and service providers. To provide for the greatest reliability and validity of answers, the same interviewer conducted each interview using the interview questionnaire found in Appendix D.

Ten inquiry areas were explored with each school administrator interviewed to provide quantifiable answers. An eleventh area was left open to explore strengths of the individual schools. The areas discussed included: (1) the optional question of the school's religious/non-religious philosophy; (2) census of special needs students; (3) identification of special needs students (process and criteria); (4) referral (process and criteria);

(5) assessment; (6) placement; (7) individualized education plans; . (8) parents' rights; (9) service delivery; and (10) funding of services. Thirty responses required sorting before tabulation; forty-two responses could be tabulated as received.

Included in each interview packet were two research participation agreements (see Appendix E), as required by the University (one copy to be kept in the school's files), and an overview sheet of the areas being probed for administrators being interviewed. 
Sample criteria. Criteria for inclusion in the interview portion of the study: (1) positive answers to at least one of the questions three through six on the survey form; (2) current (1988-89) enrollment of 50 or more students; and (3) no contra-indication of having a regular curriculum. Schools indicating a desire not to participate in the interview portion were not included. The interview sample was stratified based on religious orientation indicated on the surveys received.

Procedure. Fifteen school administrators were interviewed during February and March. A protocol titled Interview Questions/Guidelines (copy in Appendix D) was used to gain quantifiable information. Some questions were situation specific, based on survey responses and information received during the interview. Each interview was scheduled to last 45 minutes to one hour.

Analysis. Interview responses were in the form of nominal data. As defined by Charles (1988), nominal data simply name or place in categories. Descriptive statistics were used to analyze the nominal data received. 


\section{CHAPTER IV}

\section{RESULIS AND DISCUSSION}

Requirements for providing an appropriate education for students with special academic needs were detailed in the Education for All Handicapped Children Act (Davis, 1986), the Education Consolidation and Improvement Act (ECIA) of 1981, and the Bilingual Education Act and subsequent Amendments (Baca \& Cervantes, 1984). Legislated guidelines are mandatory for recipients of public monies. Since $88 \%$ of the elementary students in the United States are enrolled in public schools, it can be inferred that only $88 \%$ of that student population is being accommodated within the specified guidelines. But what of the remaining $12 \%$ enrolled in private schools (James \& Levin, 1988)? How are the needs of special students being accommodated in private schools? A two-step survey and interview procedure was used to describe how private elementary schools in Santa Clara County accommodate students with special needs.

Surveys were sent to 94 private elementary schools with a regular education curriculum enrolling 50 or more students, as listed in the 1987-88 Private School Directory. Santa Clara County, published by the Santa Clara County Office of Education. Forty-two surveys were received, a $45 \%$ rate of return. In-depth interviews were conducted with 15 administrators in schools indicating that their enrollment included special needs students. 
Nonparametric data received from both the survey and interviews were quantified through tallying. Frequency distributions were computed using the quantified data. Results are presented both graphically and narratively.

\section{Results}

Survey results are reported by answering each Survey Question separately. Interview results are grouped under the headings of Inquiry Areas.

\section{Data Presentation:Survey}

Forty-two schools (45\%) of the ninety-four schools included in the sample responded to the survey (see Appendix C) that was mailed in January 1989. The survey, designed to be answered in five minutes, contained four forced-choice questions and two open-ended questions; space was provided for additional comments. Seven school administrators declined participation in the interview process. Refer to Appendix $\mathrm{C}$ for a copy of the tabulated raw data.

Survey questions $1 \& 2$. The first two survey questions addressed the religious/non-religious orientation of the schools responding and asked for a current school census. Of the 42 respondents, 27 schools, or $64 \%$, had a religious orientation; 57 schools, or $61 \%$, were listed in the Private School Directory (1988) as having a religious orientation. The student census reported from the surveys totaled 7,962 students; $65 \%$ of the students $(5,150)$ were enrolled in $64 \%$ of the schools (religious orientation) responding.

The sizes of the schools sampled ranged from an enrollment of 25 
students to an enrollment of $\mathbf{4 5 0}$ students; the average enrollment size was 190 students. Comparative enrollment size is illustrated in Figure 1.

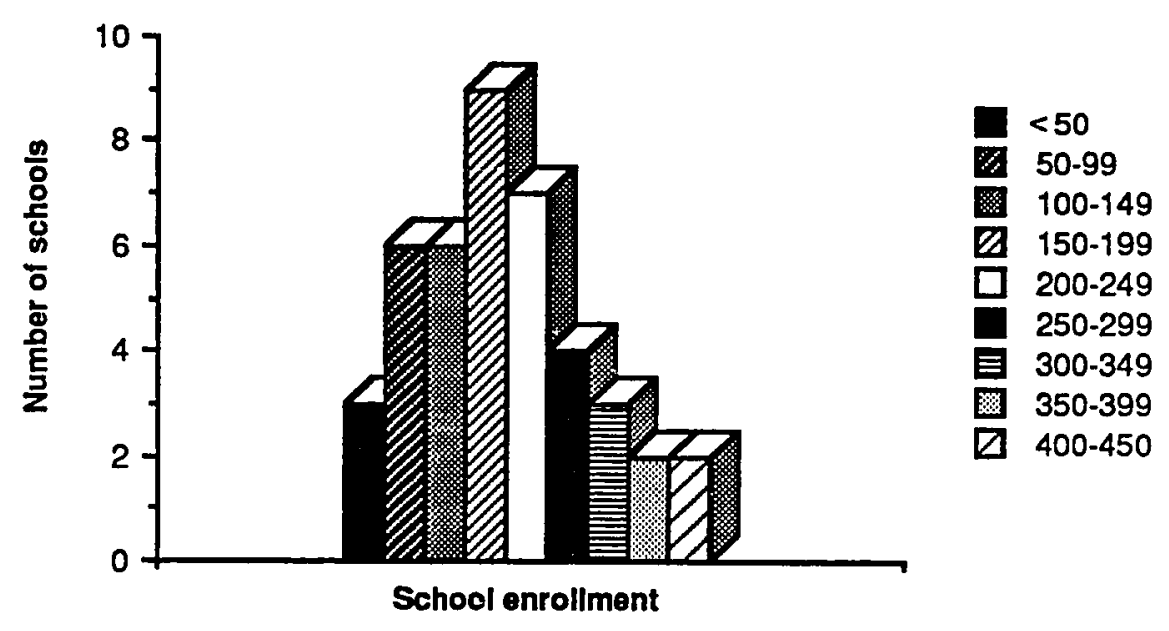

Figure 1. Comparative enrollments of private elementary schools in Santa Clara County $(\mathrm{N}=42)$.

Survey question 3. The third question was asked in two parts: (a) "Do you have any special needs students attending your school?" and (b) "If yes, indicate the kinds of special needs students enrolled." Four possible choices were listed; the fifth option, "Other: Please list," allowed for individualized responses.

Of the 42 schools responding, $86 \%$ indicated that special needs students were included in their enrollment. Based on the total responses received, learning disabled (LD) and struggling students (SS) were found in $74 \%$ of the schools; $69 \%$ of the respondents noted enrollment of students who were gifted or talented $(\mathbf{G} / \mathbf{T})$. Students who were culturally and linguistically different (CLD) accounted for 50\% of the return. Other types of student 
handicaps, $21 \%$, included limited vision, blind, physical handicaps, speech, emotional problems, and other mental handicaps. A graphic comparison of types of students found in Santa Clara County private elementary schools is illustrated in Figure 2.

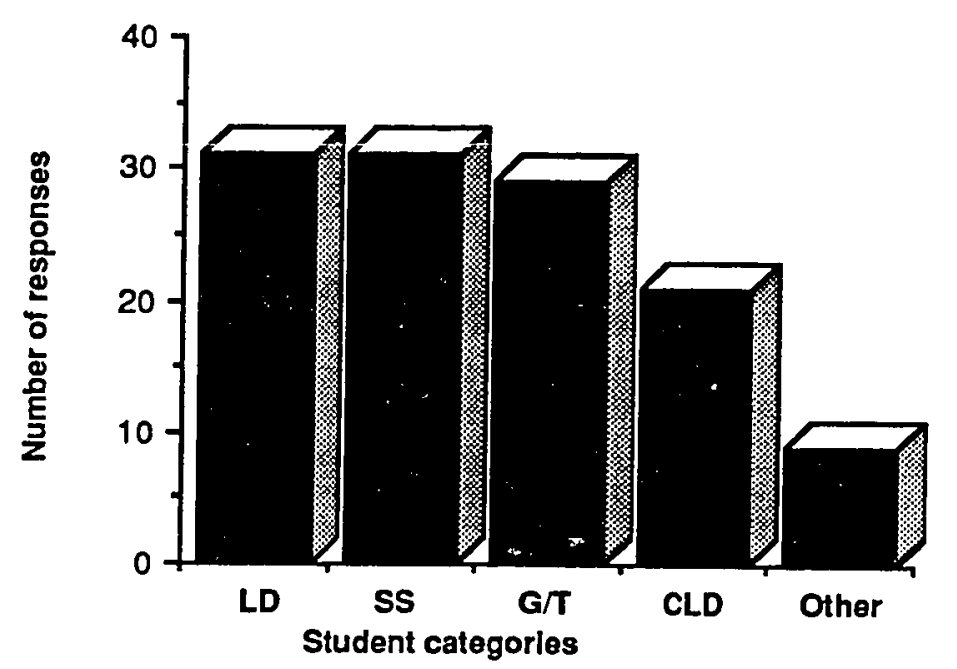

Figure 2. Types of students enrolled in private elementary schools in Santa Clara County $(\mathrm{N}=42)$.

Survev question 4. "Are any students at your school working on an individualized learning plan such as an IEP?" Twenty-four schools (57\%) of those indicating enrollments including special needs students indicated that they did not use an individualized education plan or IEP.

Survey question 5 . "What currently happens in your school when a teacher or other staff member believes that a student is struggling to keep up in class?" The parent is called in $90 \%$ of the referrals. Teachers discussed the student with other faculty members or other on-site 
personnel in $64 \%$ of the cases. A student would be referred to an on-site specialist (O/S) or resource in $60 \%$ of the schools. Referral to the public school of residence (P/S) occured in 55\% of the schools responding. The four responses to "Other" included referral to private agencies (P/P), referral to private personnel, or referral to other private schools (OPS). Patterns of student referral are illustrated in Figure 3.

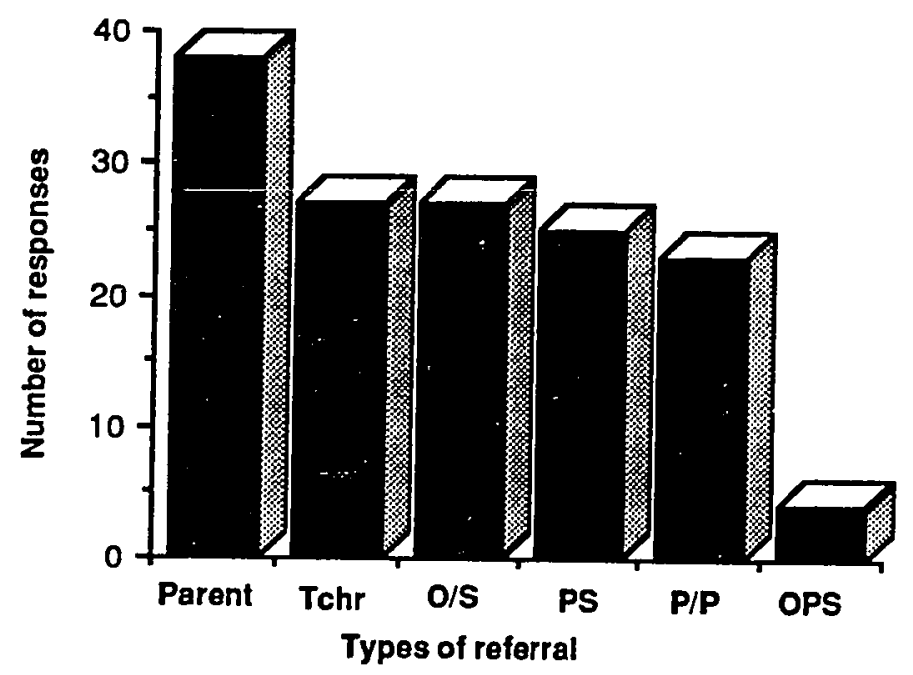

Figure 3. Responses to survey question 5 , types of referral in private schools in Santa Clara County $(\mathrm{N}=42)$.

Survey question 6. "Do you maintain contact with any public school or public school district?" The question was purposefully left open-ended to allow for individuality of responses. The responses received were categorized and then tallied. Five schools chose not to respond to this question.

Twenty-six percent of the private schools contacted the public school or district for program information or referral for testing (Ref). Twenty-two 
percent of the private schools surveyed mentioned contacting the public school or district regarding funding information (Funds). Only $11 \%$ of the private schools responding indicated having limited contact (Lmtd), while $23 \%$ indicated having no contact with the public school or district (None). Negative experiences with the public schools/districts (Neg) were reported by $9 \%$ of the respondents. Mobile vans $0:$ teachers (Tchr) were provided in another $8 \%$ of the schools.

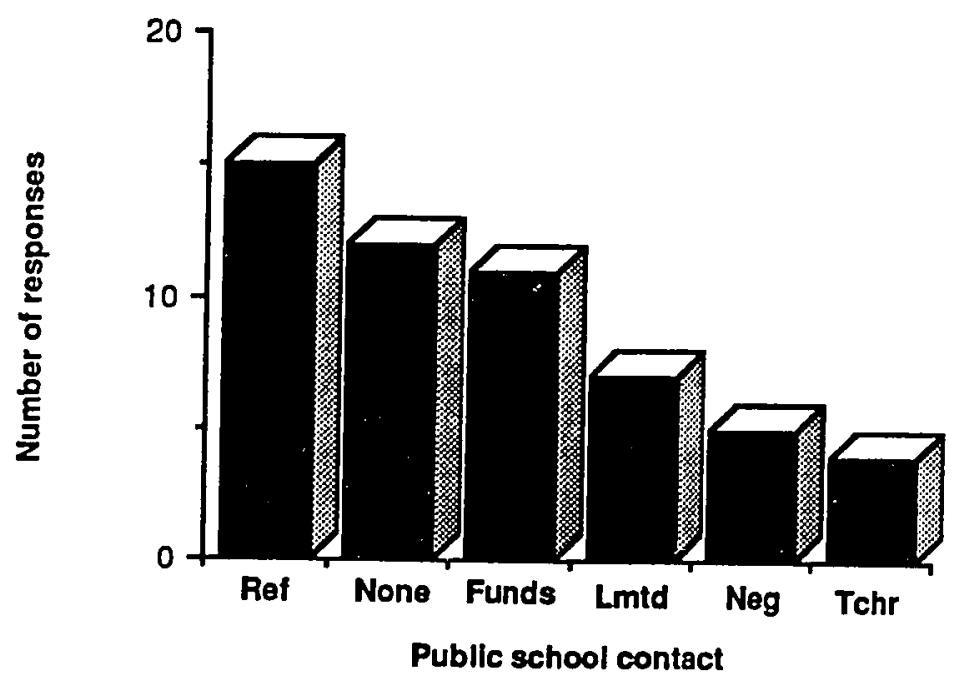

Figure 4. Responses to survey question 6 , kinds of public school contact $(\mathrm{N}=37)$.

Data Presentation: Interview (see Appendix D for protocol)

Of the 45\% return, thirty-four schools met the interview criteria: (1) no specialized curriculum; (2) current enrollment of fifty or more students; and (3) enrollment of special needs students. The interview sample was stratified to approximate the proportional percentage of schools indicating 
"religious/non-religious orientation" on the survey responses. The number of non-religious schools needed for correct stratification were not available for this interview; $80 \%$ of the interview sample is therefore composed of schools having a religious orientation, biased in favor of the religiously oriented schools rather than stratified.

Fifteen school administrators were interviewed during late February and early March 1989. To make the interview process less cumbersome, the research questions were sorted into 10 areas of inquiry, 2 of which pertained to demographics. Each interview lasted from 20 to 60 minutes, with 40 minutes being the average length of time. Complete percentages and number of responses per question are listed by Inquiry Area in Appendix D.

Inquiry area 1-religious orientation. Fifteen schools were involved in the interview portion of the study; $80 \%$ of the schools had a religious orientation. The majority of religious schools were Catholic (50\%), with Protestant and Jewish schools each accounting for $17 \%$. The remaining $18 \%$ was divided equally between fundamentalist and non-denominational schools. Two of the schools reporting a non-religious orientation described themselves as college-preparatory, with a focus on the whole child; the third non-religious private school featured a developmental curriculum.

Inquiry area 2-census of special needs students by grade. Eight schools responded to this question. Since two schools provided only estimated figures, the percentages reported should only be used for statements of general tendency: there tends to be more special needs 
students enrolled in grades $\mathrm{K}$ through $3(74 \%)$, when compared to the total estimated enrollment of special needs students.

Inquiry area 3-identification. All fifteen administrators interviewed indicated that the classroom teacher was involved in at least the initial identification of students with special needs (refer to Fig. 5).

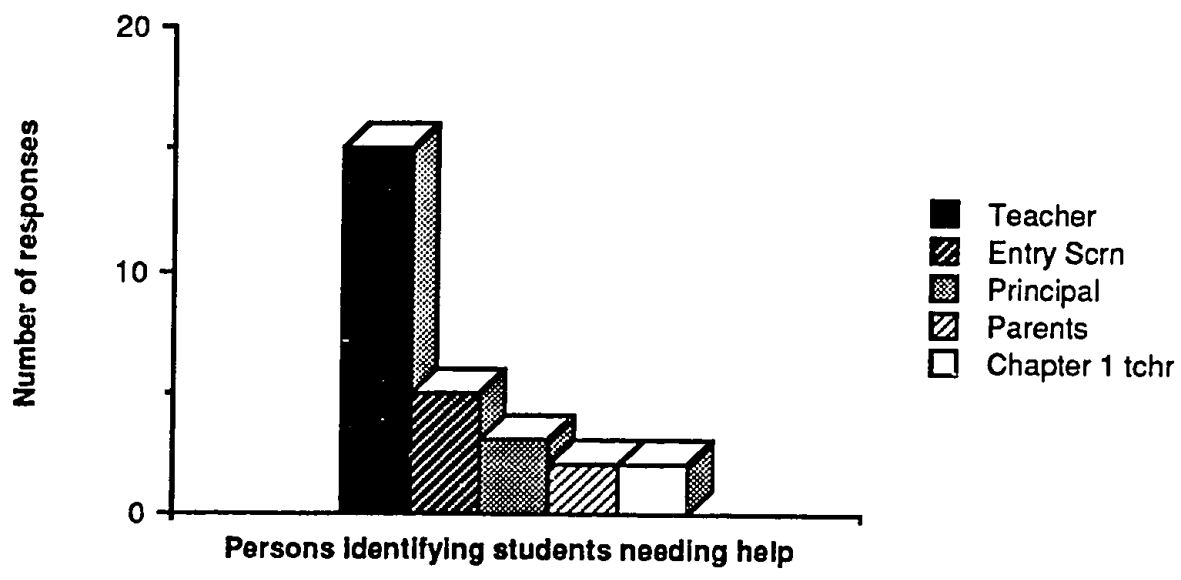

Figure 5. Persons identifying special needs students in private schools $(\mathrm{N}=15)$.

Ninety-three percent of the schools sponsored inservices or other workshops to provide additional information in identification of students with special needs. Outside specialists were featured in $67 \%$ of the inservices. Schools differed in the criteria used to identify students needing special help: attention problems were mentioned at $38 \%$ of the schools; discrepancy in expected classroom performance when compared with classmates was listed by $31 \%$ of the administrators; $23 \%$ included lack of school progress when listing criteria. Reading difficulties, classroom 
behavior, and health problems were each mentioned in $15 \%$ of the schools. Other criteria for identification included problems following directions, mathematics difficulties, or hearing problems. Two administrators mentioned concern with a student's declining self-esteem. Refer to Figure 6 for a graphic comparison of the major indicators used in identification of students with possible learning disabilities.

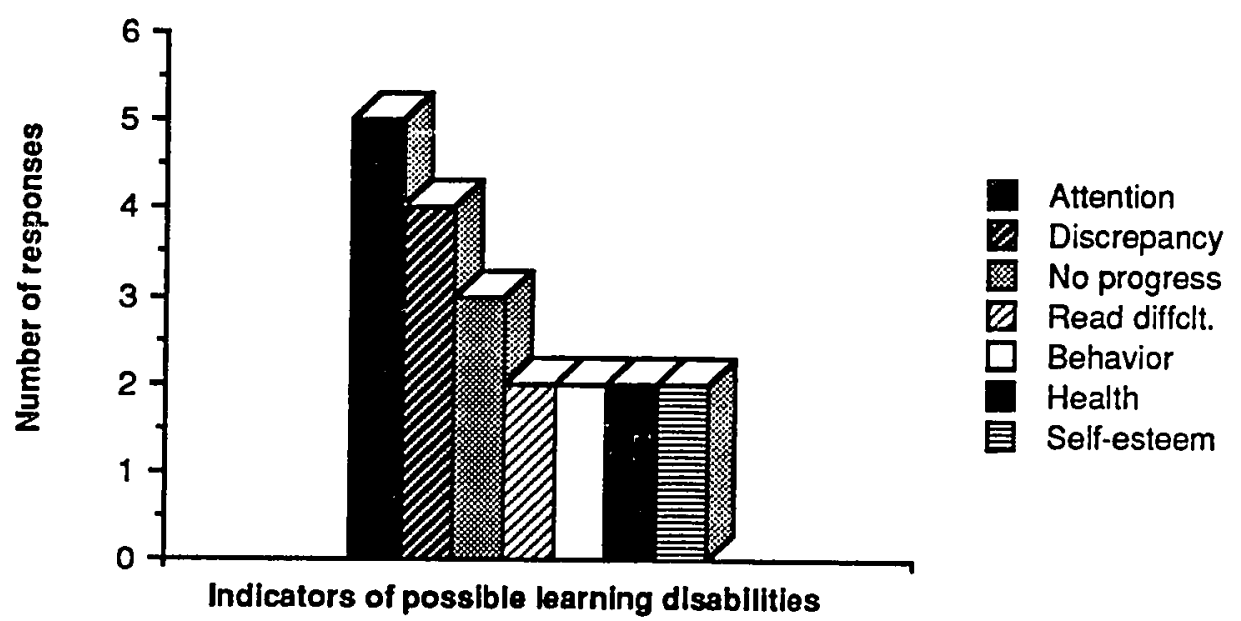

Figure 6. Indicators of possible learning disabilities reported by private schools $(\mathrm{N}=13)$.

Seven schools shared their indicators of gifted/talented students. Criteria included high reading ability; higher overall performance when compared with their classmates; high SRA scores, such as those above the 90th percentile. Nine administrators acknowledged noticing enrolled students who match the learning handicapped/gifted profile, as defined in Chapter 1. 
Inquiry area 4-referral. A formal written referral was utilized for inhouse referrals by only $20 \%$ of the schools. Thirteen percent of the schools indicated that referrals were documented. When a referral was made to a public school or district, formal paperwork was completed as required by that particular school/district. Teachers were involved in all referrals (100\%), though the specific procedures varied from school to school. Figure 7 comparatively illustrates the kinds of people involved in making referrals on-site.

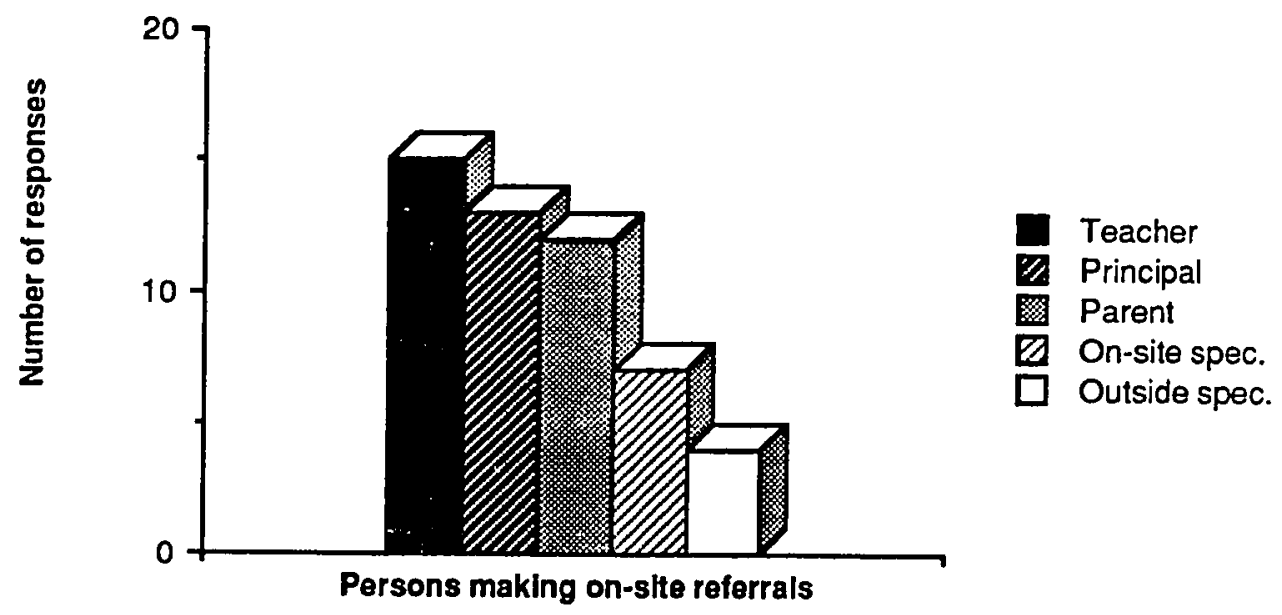

Figure 7. Persons involved in making on-site referrals at private schools $(\mathrm{N}=15)$.

A variety of referral procedures was implemented by the fifteen schools:

Teacher to principal

Teacher to principal to on-site specialist to parent

Teacher to principal to parent 
Teacher to on-site specialist to parent to principal

Teacher to parent to on-site specialist to principal

Teacher to parent to on site specialist

When a referral was made to the public school, $50 \%$ of the schools asked the parent to make the contact, while $43 \%$ indicated that the principal contacted the public school; 1 school administrator mentioned having the classroom teacher make the contact.

Inquiry area 5-assessment. More than half of the administrators interviewed (54\%) relied on the teacher's decision to proceed with the assessment process; principal input was also utilized by $46 \%$ of the schools. Pre-referral or pre-assessment strategies were used in $46 \%$ of the schools interviewed; assessment became necessary when classroom/parent strategies had not alleviated the learning difficulties.

Assessment was conducted in $71 \%$ of the schools by private agencies or private personnel on-site. Private school personnel conducted the assessments in $21 \%$ of the schools; two of these schools mentioned that onsite assessment was more of a screening process to determine if an indepth assessment was indicated, in which case the student would be referred to either the public school of residence or a private agency (refer to Fig.8). 


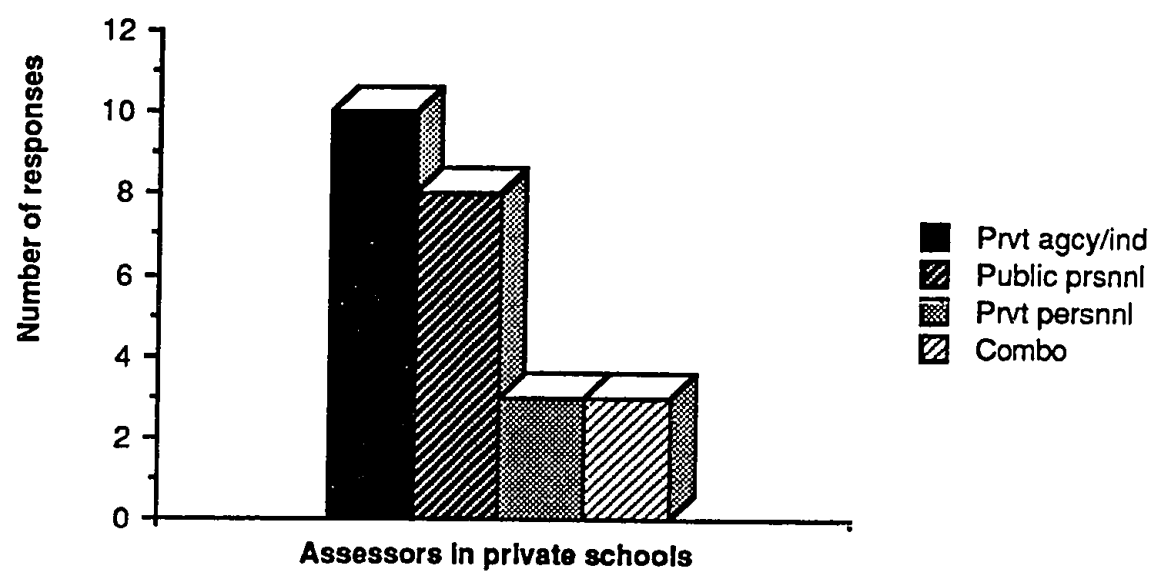

Figure 8. Personnel conducting assessments for private schools $(\mathrm{N}=14)$.

Three schools reported that assessment was done in a student's primary language. Knowledge of primary language, or language used at home, was gleaned from either the initial parent interview (73\%) or during the initial screening (27\%). Primary language was indicated at one school by the parent's choice of language to be used during the pre-kindergarten screening: either Spanish or English. A student's primary/home language was documented, usually on the application form, in fewer than half of the schools (36\%) responding to this question.

Assessment was reported to be multidisciplinary in only three of the seven schools responding. Disciplines involved in the assessment included learning disabilities specialist, speech/language therapist, occupational therapist, psychologist, or medical professional.

Follow-up assessment was conducted only as needed in four of seven responding schools. Two schools utilized a pretest/posttest assessment format. One school reported conducting assessment on a quarterly basis. 
Inquiry area 6-placement. The term placement option usually refers to determining the least restrictive environment for an individual student, specifically the choices between a full day program, special day class, or partial day program, such as the resource specialist program. Since only one of the private schools interviewed had a full day program in a special day class, the terminology applicable to the schools being interviewed was classroom options or options a school might use in accommodating students with special needs. The above terminology was used in eliciting placement option information from the fifteen school administrators.

Ability groupings within grade or class (Grp in grde) were mentioned by $80 \%$ of the 15 schools interviewed; intergrade ability grouping (Grp crssgrde) was found in $75 \%$ of the schools. Forty percent of the schools utilized cooperative learning strategies (Coop lrning). Tutoring was provided by specialists, peers, volunteer high school students, parents, and staff, depending on the school. Other options mentioned were modifications in curriculum or homework (Curr/hw mod), use of a Chapter 1 teacher (Chp 1 tchr), and retention. Figure 9 illustrates the variety of classroom options found in the private schools interviewed. 


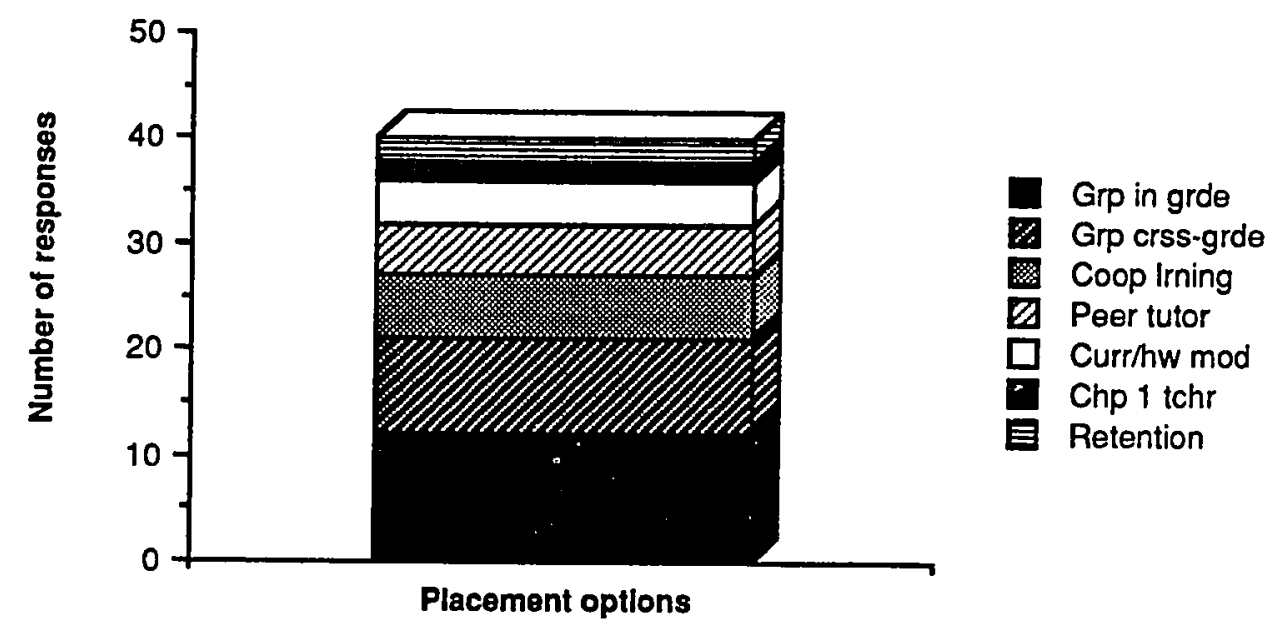

Figure 9. Comparative frequency of occurrence of placement options in private schools $(\mathrm{N}=15)$.

One administrator's private school provided a self-contained special day class: 26 students were accommodated in 3 classrooms, each of which combined two grade levels. Other schools had multi-tiered kindergarten or pre-school programs, such as developmental kindergarten or junior kindergarten. One school included students as young as 2 years; $13 \%$ of the schools received Chapter 1 services, including teachers and mobile classrooms. Another school administrator reported that $99 \%$ of the students enrolled were culturally and linguistically different.

Classroom teachers were involved in all placement/option decisions. Principals (67\%) and parents (67\%) were both involved in such intra-school decisions. Chapter 1 teachers were included in decision-making when their students were involved. Five forced-choice answers quantified results about how information was gathered to make placement/option decisions. Observations and evaluation of classroom performance were mentioned by 
all the schools participating (100\%); informal or criterion-referenced testing was utilized in $93 \%$ of the schools; formal or standardized testing, more than one test, was used in $79 \%$ of the schools; $29 \%$ of the schools relied on only one formal test for giving decision-making information. Figure 10 compares the choices for gaining decision-making information. The choices for information gathering were ranked by importance, with the most important indicated by a 1 and the least important indicated by a 4 . Single formal test and formal multi-test were combined into the category Formal Testing for ranking purposes. Classroom Performance was ranked as the most important source of decision-making information, followed by Observations and Informal Testing. Formal Testing was ranked as the least important source of information.

Classroom observations, other than teacher observations, were conducted by principals ( $79 \%$ ) or on-site specialists (64\%). Outside specialists would occasionally observe, particularly if a student's behavior was part of the reason for referral.

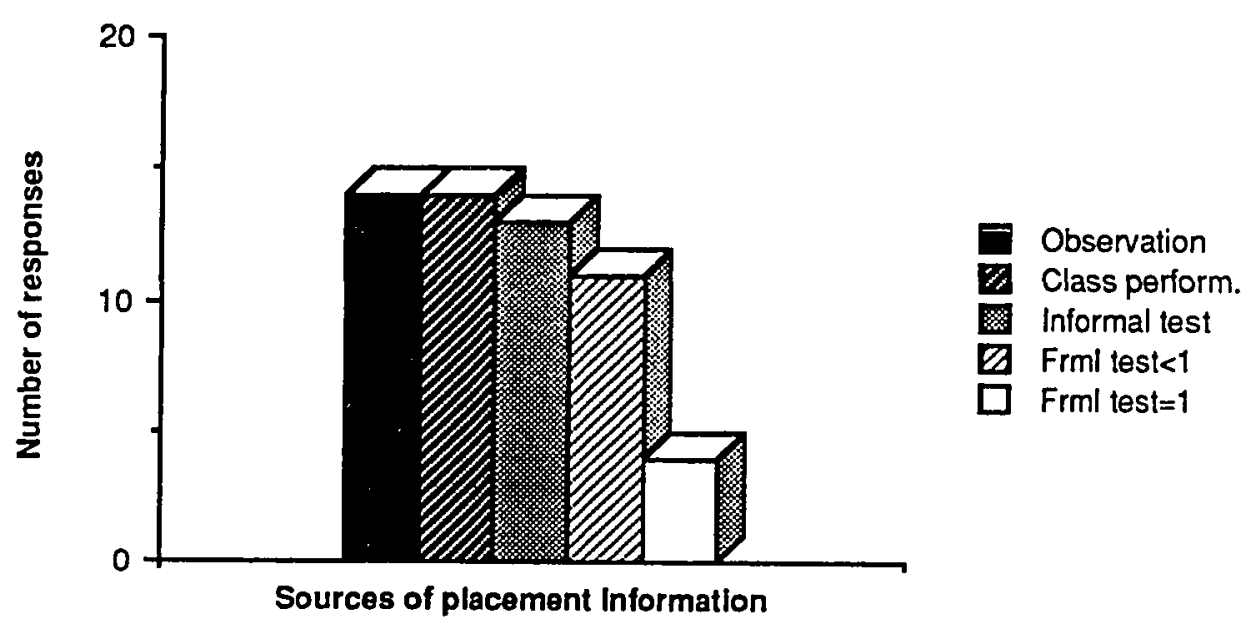

Figure 10. Sources of information for making placement/option decisions (N=14). 
Inquiry area 7-individualized educational olan. Individual educational plans were written in $64 \%$ of the schools interviewed; one school indicated that an individualized plan was written for each student. Specialists and classroom teachers were mentioned most frequently as being involved in writing educational plans (56\%); principals were mentioned as being involved in plan writing only $22 \%$ of the time. Others mentioned as being involved in plan writing were the person doing the evaluation and the parent. Figure 11 comparatively illustrates who is involved in writing individual plans.

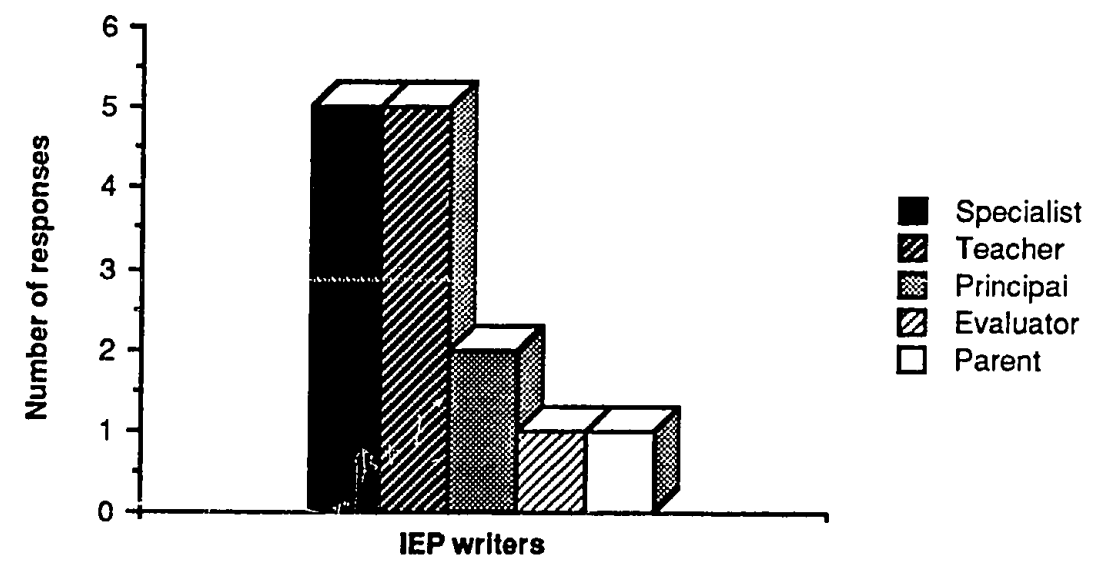

Figure 11. Persons involved in writing an individual education plan $(\mathrm{N}=9)$. The majority of the administrators (67\%) assigned responsibility for plan implementation to the classroom teacher; some administrators (33\%) assigned respunsibility to themselves. Implementation responsibility was assigned to the Learning Assistance Teacher by the school having a 
self-contained special day class.

All educational plans addressed the academic areas. Other areas that might be included were social skills, religious instruction, emotional factors, cognitive growth, and motor skills. Only two schools reported having a language component if a student is bilingual.

Inquiry area 8-parents' rights. Frincipals were responsible for safeguarding parents' rights in $86 \%$ of the schools. Responsibility was delegated only to the teacher in one school, while both the teacher and the principal shared responsibility for parents' rights in another school.

Parents were notified of a student's referral verbally by the classroom teacher $(71 \%)$ or the principal (14\%). Parents received written notification from the teacher in only $36 \%$ of the schools. Written documentation of referral was placed in the student's cumulative folder according to one administrator; another administrator sent written notification to the parents only if the student needed to be referred outside the school.

Notification of assessment was handled verbally in five of seven schools. Two schools indicated using both written and verbal methods of notification regarding assessment. Written assessment notification was listed as the sole means of communication by two of the seven schools.

All schools that utilized individual education plans $(\mathrm{N}=7)$ reported that parents were involved in developing the plan for their student. This information contradicts results in Area 7: "Who writes the plan [IEP]?" Only one school indicated that parents helped write the plan.

The interview question "How are parents informed of their right to due 
process?" appeared to be less relevant to private schools because private schools usually require some level of parental involvement. Parents' rights in general are most often published in a parent handbook.

Inquiry area 9-services. A wide diversity of services is found in private schools. A comparative illustration of service providers in private schools is shown in Figure 12. On-site services by private agencies were mentioned most frequently (60\%). Some special needs students (27\%) spent part of the day in the public school's Resource Specialist Program and the rest of the school day in the private school.

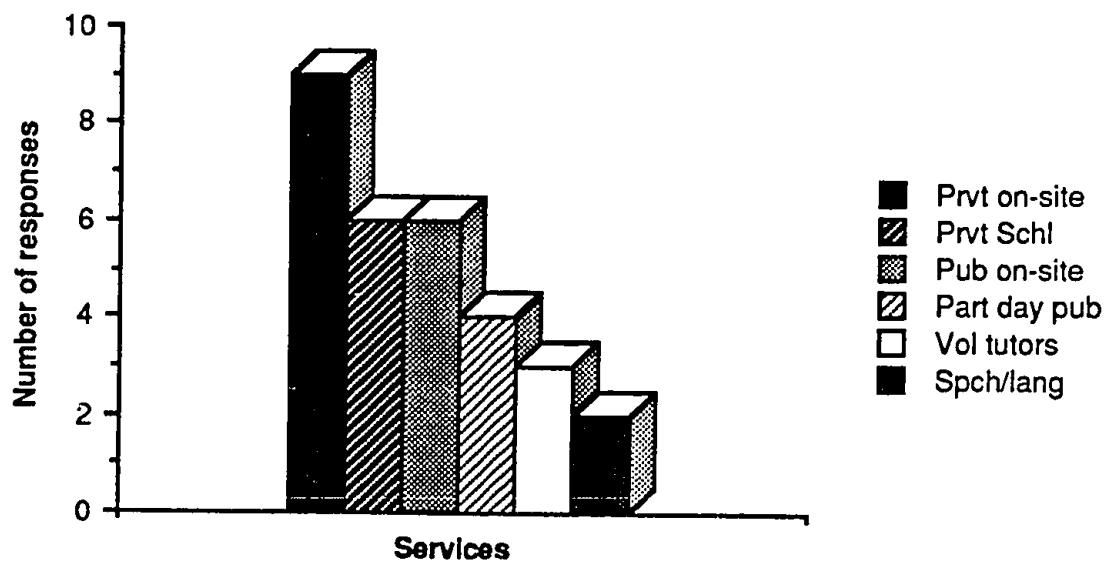

Figure 12. Service providers in private schools $(\mathrm{N}=15)$.

When asked to describe the types of services provided, all administrators mentioned one-to-one tutoring or therapy (1-1 Tut/th); Chapter 1 services (Chptr 1) were found in 27\% of the schools; speech/language therapy (Sp/lng) was reported in $20 \%$ of the schools. Other 
services mentioned included counseling, use of mobile classrooms (Mble clssrm), self-contained day class (Spec Day), instruction in English as a second language (ESL), and bilingual services.

The philosophy of the service provider was described as multisensory by $63 \%$ of the administrators; a developmental philosophy was mentioned by one school. The other schools did not know.

Tutorial services were recommended by $93 \%$ of the schools. Sixtyseven percent recommended public summer school; many private schools conducted their own summer programs. Refer to Figure 13 for a breakdown of the frequency that remediation services were recommended.

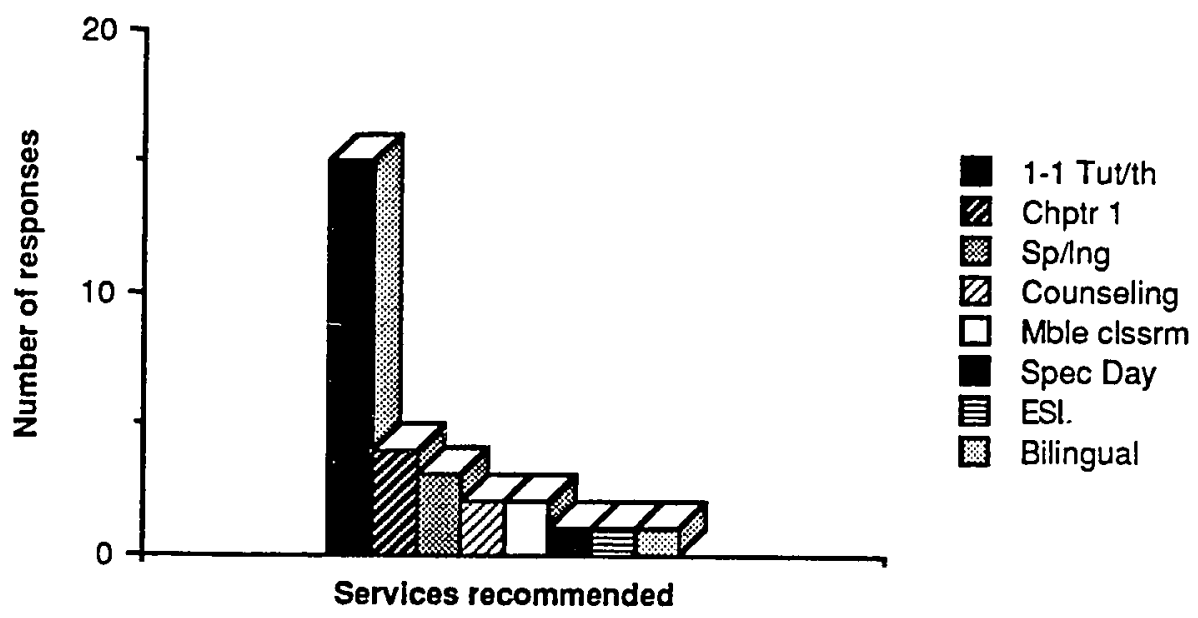

Figure 13. Remediation services recommended by private schools $(\mathrm{N}=14)$.

Inquiry area 10-funding. Individual parents were responsible for funding most on-site assessments (80\%), but some schools (40\%) did provide for assessment/screening costs within their budgets. Public school budgets provided a limited source of funds for assessment services (20\%). 
If a private agency was involved in the assessment, the parent paid the agency directly. Private schools budgeted for their own assessment costs, as did public schools.

Ninety-three percent of the schools indicated that parents fund some of the special services on-site; school budgets absorbed service costs in $53 \%$ of the schools; public schools contributed services in $27 \%$ of the schools; volunteers were found in $27 \%$ of the schools.

When private agencies or individuals were involved in providing on-site services, they were paid directly by the parents in $79 \%$ of the schools. Fifty-seven percent of the schools budgeted for on-site special services.

\section{Discussion}

The dual purposes of this study were achieved: (1) to describe the historical development of private education; and (2) to establish a base of information regarding the ways private elementary schools in Santa Clara County provide an appropriate education for students with special needs. The first purpose was achieved through historical research resulting in a description of the chronological development of private education in the United States. The second purpose was achieved through surveying and interviewing administrators in a sample of private elementary schools in Santa Clara County.

How are students with special needs accommodated in Santa Clara County's private elementary schools? Information was drawn from both the survey results and the interview results to answer the research 
questions as initially posed. Headings are provided in lieu of re-stating the research questions.

Accommodation of special needs students. Based on the survey results, $86 \%$ of the private elementary schools in Santa Clara, primarily having a religious orientation, accommodate students with special needs. A broad spectrum of special needs categories were found ranging from struggling students through mild learning disabilities to low-incidence physical handicaps. Several schools reported enrollment of culturally and linguistically different students (CLD) as well as students who could be called gifted/talented. The existence of the emerging category of the learning disabled/gifted was confirmed. The category of struggling students was not a formally identified group of students, but was specific to the purposes of this study: it was hypothesized that some schools might define students with mild learning handicaps as struggling students if formal identification had not yet taken place.

Enrollment of special needs students was higher in grades $K$ through 3 than in grades 4 through 6 . The apparent emphasis was on prevention as demonstrated by giving learning assistance when it is needed. Private schools can be more flexible in helping mildly handicapped or struggling students since they are not limited by the state-interpreted criteria of identification of any disability: learning assistance is dependent upon choice, not definition.

Identification. Students with special needs were flagged through school screening before admittance; by school-wide achievement testing; by 
examination of past records; or by demonstrated achievement or behavior in the classroom. The classroom teacher was usually involved in initial or pre-referral identification. Formal identification was made by specialists either on-site, from outside agencies, or from the public school.

Most schools interviewed (93\%) indicated facilitating inservices where specialists provided more information on the identification of special needs students, or on the development of pre-referral classroom strategies. Indicators of possible learning problems usually included mention of limited attending skills. Discrepancies in a student's performance when compared to other classmates or lack of progress in the classroom were both definite causes for concern. Other indicators or red flags mentioned were poor classroom behavior, frequent health problems, declining selfesteem, and reading difficulties.

Gifted or talented students exhibited an overall higher classroom performance than their classmates. This higher performance took the form of high SRA scores or greater demonstrated ability in reading or math. Several schools indicated having an enriched curriculum available to all students, not just gifted or talented students.

The indicators or profiles of both the learning disabled and the gifted were combined into an emerging category called learning handicapped/gifted: students who have the characteristics of giftedness, but are being limited to expression of their superior skills in only their intact modalities (Kitano \& Kirby, 1986). When queried about this emerging 
category, the administrators being interviewed acknowledged the existence of learning handicapped/gifted students in their schools.

Referral. Private schools in Santa Clara County use informal rather than written procedures when referring a student to in-house personnel; when referring to a public school or district, paperwork required by that school/district would be used. A variety of referral procedures were described (see Appendix D), all of them beginning with the classroom teacher. Few schools (13\%) document a student's referral. Notification of in-house referral was usually verbal; written notification to parents upon a student referral, as required by law (California Deptartment of Education, 1988, p. 163), occurred in only half of the schools. The referral process to the public school or district was initiated by either the parent or school personnel, often with parental support provided by the school.

Assessment. Only a small percentage of the schools (21\%) reported conducting formal evaluations on-site. On-site assessment was more often used as a screening to determine if a full evaluation was, in fact, necessary. The decision about whether or not evaluation should take place was made most often by the classroom teacher when classroom strategies, or prereferral strategies, had not worked. The decision was usually made after input from either specialists or the principal.

Since private agencies or individuals were responsible for the assessment in $71 \%$ of the schools, it was not possible to determine if the evaluations were multidisciplinary without interviewing the agencies involved. Of the seven schools conducting on-site assessment, three 
reported that their evaluations were multidisciplinary involving a combination of specialists from the fields of learning disabilities, speech/language, occupational therapy, psychology, or medical profession. The combination of specialists utilized was based on the information needed for that particular student. Follow-up testing was conducted on an asneeded basis rather than at regularly specified intervals.

Assessment was conducted in the student's native language in those schools reporting enrollment of students more proficient in a language other than English. Determination of primary or home language was accomplished most often during the parent interview. Home language, when documented, was usually included on the application form. Private schools currently enrolling CLD students stated that they were not aware of the state requirement of having a Home Language Survey or similar documentation on file (California Department of Education, 1988, EC 62002, p. 111). State or federal statutes are often applicable only to those receiving public monies; the philosophy behind the statute is often, however, in the best interests of the student, as with the Home Language Survey (Baca \& Cervantes, 1984).

Individualized education plan (IEP). Survey results indicated $57 \%$ of the schools enrolling special needs students utilized some form of IEP. Goal statements, a modified form of individualized education plan, were often used in one-to-one tutoring. The education plan is usually written by the classroom teacher or specialist. Some schools sought input from the principal or parent. The classroom teacher, including the Learning 
Assistance Teacher in the school with the self-contained day class, was designated as responsible for IEP implementation in most of the schools (67\%). The IEP of a bilingual student contained a language component. Other components mentioned by the administrators interviewed included academic, social, religious, emotional, cognitive, and motor.

Placement. Placements were decided, or options chosen, in the private school by the classroom teacher only if the decision concerned pre-referral strategies. Parents and principals were involved in decision-making at only $67 \%$ of the schools. The greater the parent involvement in the school, the less the formal contact about placement options.

Classroom observations by teachers, principals, or specialists, and classroom performance were two factors considered by all schools in decision-making. Information was also gained through informal testing (93\%) and formal testing (79\%), using more than one test. Only $29 \%$ of the schools relied on information from only one test, usually a school-wide achievement test. When the four factors were ranked in order of importance of information gained for making decisions, a student's classroom performance was considered the most important. Observations were second in importance, with informal testing and formal testing third and fourth, respectively.

Service providers. Special education services vary for a student who has qualified for services in the public school system, yet chooses to remain in the private school. Services are most often provided on-site through a private agency $(60 \%)$. Some private schools (40\%) also provide services for 
these students. Public schools provided some on-site services (40\%), such as Chapter 1 or other Designated Instructional Services (DIS); qualifying private school students (27\%) attended public school for part of the school day for assistance from the resource specialist.

On-site one-to-one tutoring or therapy sessions were found in all schools (100\%). Chapter 1 services (27\%) and speech/language services $(20 \%)$ were the next most frequently mentioned services. Other on-site services mentioned were counseling; mobile van or classroom; instruction in English as a second language; self-contained day class; and bilingual services. Many providers used a multi-sensory approach (63\%), but the philosophy of $25 \%$ of them was unknown. One school, having a developmental philosophy, included only providers with a similar philosophy.

Tutorial services were recommended by almost all schools (93\%) as a supplement to classroom instruction. Public summer school was recommended in only $67 \%$ of the cases since several schools sponsored their own summer school. Other remediation services recommended included community services, counselors, other private schools, occupational therapy, and speech/language services.

Funding. Parents provide funds for $80 \%$ of the assessment services and $93 \%$ of the remediation services provided at the private school. Some schools included services, assessment (40\%) or remediation (53\%), in their budgets, reflecting additional parental monetary contribution. Services provided by the public school were paid from public funds. Tutorial services 
were often provided by volunteers, such as high school students satisfying community service requirements.

Safeguarding parents' rights. This question was not as relevant for private schools as for public schools. Private schools usually require some level of parental involvement resulting in more parent knowledge about a student's difficulties in school. Parents' rights, in general, are most often published in a parent handbook.

\section{Conclusions}

On the whole, education for the mildly handicapped is alive and well in private schools in Santa Clara County. The private school setting is unique in its ability to focus on a student's needs rather than on identification criteria and accompanying paperwork. The cost of services frustrated some of the private school administrators : these administrators would like to provide more services, but they are not always sure how without a high cost to the parents.

Several private school administrators had a very good working relationship with personnel in the surrounding public school district, sharing assemblies or other school functions. These schools seemed to be in the minority. Administrator frustration was expressed in trying to work with some public schools in providing the best educational experience for the student.

Private schools play an important role in providing choices for educational opportunity to reach the fundamental ideals and values of 
school as listed by Ysseldyke and Algozzine (1982): "democracy, nationalism, and individualism...[translated into] the four basic values ...[of] the worth of the individual, the equality of all individuals, the equality of opportunity, and faith in reason (p. 212)."

These ideals and values might be translated into reality with the goals suggested by Hirschoff (1986) for all education: (1) parental choice of school environment; (2) acceptance of pluralism or diversity in schooling; (3) acceptance of pluralism or diversity in society; (4) equal educational opportunity; (5) equal access to the same basic values, skills, and knowledge; (6) educational quality as manifested in minimum schooling standards; (7) instructional effectiveness; (8) responsiveness; (9) efficient allocation of resources; and (10) efficient use of resources. Only 7 of the 10 goals or values listed pertain directly to private schools: acceptance of pluralism or diversity in society (number 3 ) pertains more to the attitude of society as a whole than to schools, although changing society's attitude can begin in the schools; efficient allocation of resources (number 9) is dependent upon legislative bodies, when the word resources is translated as meaning dollars. Equal access to the same basic values, skills, and knowledge (number 5) would apply jointly to private and public schools.

Comparison of the research data with Hirschoff's (1986) goals indicated that Santa Clara County's private schools do provide the clisice of environment; are an expression of the diversity in our American culture; and have the capability of being very responsive to students' needs. A private school's continued existence depends on efficient use of resources, 
therefore the assumption is made by default that the private schools interviewed make efficient use of their resources. Educational opportunity is equal to all those enrolled, but enrollment sometimes is dependent on criteria that is situation-specific. Determination of instructional effectiveness would require further study.

Schooling standards are ambiguous for private schools (ECS, 1984), but are being met as required in the state of California. This ambiguity in the law, places California's private schools in an awkward position: on one hand, the law has few requirements for them, yet they are expected by parents to provide a current and thorough education for students. Private schools, according to California State Law, Education Code 33190, are only required to register annually by filing an affadavit listing census by grade, number of teachers and administrators, and indicating compliance with local ordinances, such as fire or building codes. Teachers are not required to hold a credential unless teaching formally identified exceptional children. A private school does, however, need to investigate and follow any local health and safety ordinances.

\section{Recommendations for Further Research}

Overview research on how private schools accommodate special needs students in Santa Clara County has now been initiated with this descriptive study. Research should now focus on generating in-depth information on how a specific aspect of statutory requirements affecting the education of students with special needs is being implemented in private schools. The overview study model could be broadened to include private schools in other 
counties or states.

Comparisons of how private and public schools are providing for students with special needs could also be examined. Such a comparison study might utilize the Coordinated Compliance Monitoring Review Manual (CCMRM), published by the California State Department of Education. The 1988-89 CCMRM was designed to be used by California's public schools for self-review of compliance with requirements of several federally funded programs. If the same criteria were applied to both public and private schools, the results could be equitably compared.

Lerner's (1989) three stages of the IEP process, referral, assessment, and intervention, could also provide the framework for comparing performance in public and private schools.

Research is needed to determine the quality of services being provided in the private schools. What makes an effective private school? Research detailing the effectiveness of various service delivery models in the private schools is also needed.

Research could be completed that would clarify the functioning and mandates of the Nonpublic Schools Unit of the California State Department of Education. The Advisory Committee providing input to this unit should also be evaluated to determine representativeness.

It appeared that the success and programs of the private schools visited was dependent upon the quality of the administrator. How do administrators in private schools keep up-to-date about legislation, 
educational research, and teaching techniques? What makes a good administrator of a private school?

Theoretical research is needed to focus on the pros and cons of government intervention, both monetarily and regulatory. Some research has been conducted in this area, but the results have not yet been compiled. 


\section{CHAPTER V}

\section{SUMMARY}

The purposes of this study were (1) to describe the historical development of private education, including the relationship between government and the private school; and (2) to establish a base of information regarding the ways private elementary schools in Santa Clara County provide an appropriate education for students with special needs, specifically learning disabled, culturally and linguistically different, and learning handicapped/gifted in the areas of identification of needs, referral, assessment, delivery of special services, and protection of parents' rights as defined in P.L. 94-142.

The first purpose of the study, a chronological development of private education, was completed after several extensive literature searches. The past has definitely left its mark on the present: even our forefathers were human - something was left out of the Constitution. What would life be like if education had been included in the Constitution? Much of the current confusion and debate about public monies and private schools would no longer be necessary. Would similar debates of the 1800 s have been unnecessary? What would public schools be like today? Would private schools now have the dollars needed to lower tuition? Would there be private and public schools as we know them? 
The Whig philosophy and the Jacksonian Democratic philosophy emphasized the duality of the philosophical legacy of our founding fathers: individual freedom versus the greatest societal good. Special education and regular education try to walk the narrow balance between the two. Civil rights walks the same balance beam as does any elected official. Nativism is the extreme, or imbalance, where the individual has the stronger power. The detrimental effects were seen in Oregon in 1925 and in California with the exclusion of certain minority groups over the years.

The second study purpose, establishing a base of information about the implementation of special education legislation in private schools, required descriptive research. A two-step survey and interview procedure was used to gather information from private schools in Santa Clara County meeting the research criteria. Raw data were tabulated and analyzed. The results were presented both narratively and graphically as appropriate.

Survey subjects included all the private elementary schools in Santa Clara County having a 1987-1988 enrollment of 50 or more students. The schools receiving the survey also needed to have a regular curriculum as opposed to a specialized curriculum.

A stratified sample of interview subjects was selected from among those schools responding to the survey; indicated a 1988-89 enrollment of 50 or more students; included students with special needs; and gave no contra-indication of having other than a regular curriculum.

Forty-two surveys (45\%) were returned in early February. 
Administrators of 15 schools were interviewed in February and March. The survey and interviews were designed to elicit descriptive information about how private elementary schools in Santa Clara County accommodate students with special needs.

Education for the mildly handicapped is vigorously adapting to perceived need in the private schools of Santa Clara County. The private school setting is unique in its ability to focus on a student's needs. Frustration by several administrators was expressed about the cost of the services: schools would like to provide more student services, but are not always sure how to provide the services without charging parents an everincreasing amount.

Overview research on how private schools accommodate special needs students has now been initiated with this descriptive study. Research should now focus on generating in-depth information on a specific aspect of statutory requirements affecting the education of students with special needs.

This research has resulted in an odyssey from one end of the Santa Clara Valley to the other, and from the seventeenth century through the twentieth century. During this journey, man's insensitivity to man has been explored, and yet private schools continue to provide a varied program for their students, consisting not only of the three Rs, but more importantly consisting of the three Cs: caring, compassion, and concern for the 
individual. One step has been taken in defining how private schools of today are accommodating students with special needs; many more steps need to follow to complete the picture. 


\section{REFERENCES}

Baca, L. M., \& Cervantes, H. T. (1984). The bilingual special education interface. Columbus, Ohio: Charles E. Merrill Publishing Company.

Benway, M. P. (1983). The church-state relationship: A historical and legal perspective. Contemporary education, 54. Terre Haute, IN: Indiana State University School of Education.

Best, J. W., \& Kahn, J. V. (1986). Research in education (5th ed.). Englewood Cliffs, NJ: Prentice-Hall.

Brown, R. D. (1976). Modernization: The transformation of American life:1600-1865. New York: Hill and Wang.

Brown v. State Board of Education of Topeka, 347 U.S. 483, 493 (1954).

California State Department of Education. (1989). California special education programs: A composite of laws (revised to cover laws enacted during 1988). Sacramento, CA: Author.

California State Department of Education. (1988). 1988-89 coordinated compliance monitoring review manual. Sacramento, CA: Author.

Chambers, J. G. (1988). Patterns of compensation of public and private school teachers. In T. James \& H. M. Levin (Eds.), Comparing public \& private schools: Vol, 1. Institutions and organizations (pp. 190-217). Philadelphia, PA: The Falmer Press. 
Charles, C. M. (1988). Introduction to educational research. White Plains, NY: Longman Inc.

Cooper, B. S. (1988). The changing universe of US private schools. In T. James \& H. M. Levin (Eds.), Comparing public \& private schools: Vol. 1. Institutions and organizations (pp. 18-45). Philadelphia, PA: The Falmer Press.

Cremin, L. A. (1964). The transformation of the school: Progressivism in American education. 1876-1957. New York: Vintage Books.

Davis, W. E. (1986). Resource guide to special education: Terms / laws / assessment procedures / organizations (2nd ed.). Newton, MA: Allyn and Bacon, Inc.

Education Commission of the States, Law and Education Center (ECS). (1984). State legislative policies on private education. (Grant NIE-G-0007). Denver, CO: Author. (ERIC Document Reproduction Service No. ED 248 599)

Ensign, F. C. (1969). American Education: Its men, ideas and institutions. New York: Arno Press \& The New York Times. (Original work published in 1921 as Compulsory school attendance and child labor. Iowa City, IA: The Athens Press)

Gallagher, J .J. (1988, October). "National agenda for educating gifted students: Statement of priorities". Exceptional Children, 55, 107-114. Reston, VA: Council for Exceptional Children. 
Goda, Paul, S. J. (1967). The historical background of California constitutional provisions prohibiting aid to sectarian schools. The California Historical Society Quarterly, 46, pp. 99-188.

Hammill, D. D., Leigh, J. E., McNutt, G., \& Larsen, S. C. (1987). A new definition of learning disabilities. Journal of Learning Disabilities, 20 , 109-113.

Hendrick, I. G. (1980). California education: A brief history. San Francisco: Boyd and Fraser Publishing Company.

Heward, W. L., \& Orlansky, M. D. (1980). Exceptional children.

Columbus, OH: C.E. Merrill Publishing Company.

Hirschoff, M. M. U. (1986). Public policy toward private schools: A focus on parental choice. In D. C Levy (Ed.). Private education: Studies in choice and public policy, pp. 33-56. New York: Oxford University Press.

James, T., \& Levin, H. M. (Eds.). (1988). Comparing public and private schools: Vol 1, Instituicions and organizations. Philadelphia, PA: The Falmer Press.

Jorgenson, L. P. (1987). The state and the non-public school: 1825-1925.

Columbus, MO: University of Missouri Press.

Katznelson, I., \& Weir, M. (1985). Schooling for all. Berkeley, CA: University of California Press.

Kirk, S. A., \& Gallagher, J. J. (1979). Educating exceptional children (3rd ed.). Boston: Houghton Mifflin Company. 
Kitano, M. K., and Kirby, D. F. (1986). Gifted education: A comprehensive view. Boston, MA: Little, Brown and Company.

Lerner, J. W. (1989). Learning disabilities: Therories, diagnosis, and teaching strategies (5th ed.). Boston, MA; Houghton Mifflin Company.

Levy, D. C. (1986). "Private" and "public": Analysis amid ambiguity in higher education. In D. C. Levy (Ed.), Private education: Studies in choice and public policy, pp. 170-192. New York: Oxford University Press.

Lines, P. M. (1983). Private education alternatives and state regulations. Journal of law and education, 12, 189-234.

Lines, P. (1985). Compulsory education laws and their impact on public and private education (Report No. LEC-84-11). Denver, CO: Law and Education Center, Education Commission of the States. (ERIC Document Reproduction Service No. ED 253-963)

McGee, J. C. (1987). Compulsory education: An overview of the law. Sam Houston State University, Huntsville, TX. (ERIC Document Reproduction Service No. ED 285 249)

Public Law 97-35 (P.L. 97-35). Omnibus Budget Reconciliation Act of 1981. 95 Stat. 357.

Pulliam, J. D. (1982). History of education in America (3rd ed.). Columbus, OH: Charles E. Merrill Publishing Company. 
Riggen, T. F., DeForrest, E. G., Holmes, D. L., Kaufmann, P., Long, E. W., II, \& McGlamery, R. (1987). CECANAPSEC task force to develop guidelines for effective cooperation between public and private schools in meeting legal and professional responsibilities for the education of children with disabilities. (Available from The Council for Exceptional Children, 1920 Association Drive, Reston, VA, 22091).

The Santa Clara County Office of Education. (1988). Private school directory : Santa Clara County 1987-88. San Jose, CA: Author.

Stickney, B. D., \& Marcus, L. R. (1984). The great education debate: Washington and the schools. Springfield, IL: Charles C. Thomas.

Stone, J. C., \& Schneider, F. W. (1971). Eoundations of education: Vol 1; commitment to teaching (2nd. ed.). New York: Thomas Crowell Company.

Ysseldyke, J. E., \& Algozzine, B. (1982). Critical issues in special and remedial education. Boston, MA: Houghton Mifflin Company. 


\section{APPENDIX A}

\section{SELECTED LEGISLATION AFFECTING PRIVATE ELEMENTARY} EDUCATION 


\begin{tabular}{|c|c|c|}
\hline Date & Level & Title and Contents \\
\hline 1642 & MA Colony & $\begin{array}{l}\text { Massachusetts Compulsory School Law, } \\
\text { A grammar school in each town of } 100 \text { families, } \\
\text { and a master with the ability to teach reading and } \\
\text { writing in each community of } 50 \text { families; literary } \\
\text { education. }\end{array}$ \\
\hline 1647 & MA Colony & $\begin{array}{l}\text { Old Deluder Satan Act. Communities must } \\
\text { provide schools or give neighboring community } \\
\text { money for schools. }\end{array}$ \\
\hline 1866 & & $\begin{array}{l}\text { Establishment of the Freedman's Bureau: } \\
\text { appropriation of } \$ 521,000 \text { to support schools for } \\
\text { recently freed slaves. }\end{array}$ \\
\hline 1867 & Federal & $\begin{array}{l}\text { Department of Education created - not a Cabinet- } \\
\text { level position. }\end{array}$ \\
\hline 1869 & Federal & $\begin{array}{l}\text { Department of Education name changed to Office } \\
\text { of Education; placed under Secretary of Interior. }\end{array}$ \\
\hline 1870 & Federal & $\begin{array}{l}\text { Office of Education renamed Bureau of } \\
\text { Education. }\end{array}$ \\
\hline 1920 & & $\begin{array}{l}\text { Mineral Lands Act. A portion of monies gained } \\
\text { from mineral development on federally owned } \\
\text { land would be returned to those states where the } \\
\text { development occurred. }\end{array}$ \\
\hline 1929 & Federal & $\begin{array}{l}\text { Bureau of Education renamed Office of Education. } \\
\text { Beginning Great Depression. New Deal } \\
\text { Programs that included education monies: } \\
\text {-relief funds from Federal Emergency Relief } \\
\text { Administration paid salaries and put two - three } \\
\text { million dollars per month into education; } \\
\text {-Works Progress Administration (WPA) spent } \$ 22 \\
\text { million to keep schools open for complete } \\
\text { academic year; -WPA also served school lunches; } \\
\text {-Civilian Conservation Corps; -National Youth } \\
\text { Administration. }\end{array}$ \\
\hline
\end{tabular}


1941 Federal Lanham Act. Aid to impacted school districts. Dollars to communities with federal installations such as defense plants and military bases to help defray costs.

1946 Federal National School Lunch Act. Low cost lunches for all school children.

1950 Federal National Science Foundation Act. Encouraged

1954

1958 curriculum development in sciences and math. Subsidized milk for school children

1960

1964

1965

Federal

National Defense Education Act. Increased use of language labs.

Free or reduced price meals to children of families below poverty level.

Federal Civil Rights Act. Public schools to accept all children regardless of race, religion, color or national origin; Attorney General empowered to seek court action against non-compliant schools. Federal Elementary and Secondary Education Act (ESEA). Broad based federal aid "to all impoverished children regardless of whether they were enrolled in public or private schools" (Stickney \& Marcus, 1984, p. 31).

Federal ESEA broadened to include handicapped.

1968 Federal

Vocational Education Act. Part 6 of Amendments required states to ensure that appropriate nonprofit private school students receive services on an equitable basis.

1972

Federal ESEA Amendments added bilingual education. Federal Elementary and Secondary Education Amendments. Included Emergency School Aid Act and creation of National Institute of Education. disadvantaged; contains bypass clause; Title IV libraries, learning resources, education innovation and support; Title VII - Bilingual Education, bypass clause added in 1978 . 
1975

1978

1979

1980

1981
Federal

Federal

CA State Federal

MA State Federal
Education for All Handicapped Children Act (P.L. 94-142). Landmark legislation mandating a free and appropriate education for all children with handicaps. A bypass clause is included.

Education Amendments of 1978.

Department of Education Organization Act.

Created the Cabinet-level Department of

Education: consolidated the work of 40 different federal agencies except for Head Start (left with Department of Health \& Human Services), school lunch \& nutrition programs remained in Department of Agriculture, Indian education programs left with Department of Interior. Proposition 13 - initiative. Limited tax income. P.L. 96-88. Local authorities were to maintain primary authority over education, regardless of the creation of a Department of Education. Proposition $21 / 2$ - initiative. Limited tax income. Omnibus Reconciliation Act. 57 categorical programs consolidated into nine block grants, Reagan's attempt to "augment...state and local authority" (Stickney \& Marcus, 1984, p. 110). Title V pertains to Education Programs and is called the Omnibus Education Reconciliation Act of 1981. Title V, Subtitle D is the Elementary and Secondary Education Block Grant or Education Consolidation and Improvement Act of 1981. Programs started under 1974 Amendments became 1978 Amendments which in turn became Chapter 1 and Chapter 2 programs, unless kept separate: P.L 94-142, Head Start, Women's Educational Equality Act, Vocational Education Program, Bilingual Education Program. Bypass provisions are included. 
APPENDIX B

SELECTED LITIGATION AFFECTING PRIVATE ELEMENTARY SCHOOLS 


\section{Date}

1925

1954

1971

1972

\section{Title and Contents}

Pierce v. Society of Sisters of Holy Names of Jesus and Mary, 268 U.S. 510 (1925). Suit brought in reaction to Oregon law requiring students to attend only public schools. Supreme Court ruled in favor of Society and defined state's powers regarding schools as one of regulation, inspection, and supervision of curriculum and teachers; specifics up to the individual states. States do not have the general power of standardizing children by forcing them to attend any given school. Brown v. Board of Education, 347 U.S. 483 (1954). Separate educational facilities are inherently unequal. Brown was "landmark, not only that it put an end to the constitutionality of 'separate but equal' but that it opened the school to federal scrutiny in order to guarantee that the 'equal protection' and 'due process' clauses of the Constitution do not stop at the school house door" (Stickney \& Marcus, 1984, p. 129).

Lemon v. Kurtzman 403 U.S. 602 (1971). Three-pronged test to determine if students in church schools can constitutionally receive public monies: "(1) aid must be intended to promote a student's education, health, and safety, not to enhance religion; (2) the primary effect of the aid must be religiously neutral; (3) the aid program must be such that it can stand without excessive surveillance that would result in government entanglement in the affairs of the church" (Stickney \& Marcus, 1984, p. 140). Wisconsin V. Yoder, 406 U.S. 205 (1972). "If any religious group [Amish in this case] is able to demonstrate that compulsory education laws interfere with the group's established religious approach to the preparation of its youth for responsible adulthood, the law must yield to the supremacy of the religious practice" (Stickney \& Marcus, 1984, p. 138). 
Meek v. Pittenger, 421 U.S. 349 (1975). Permitted the loaning of public school textbooks to parochial schools, but ruled "direct aid [to parochial schools] in the form of the provision of auxiliary services (counseling, testing, speech therapy, etc.) [is] noncompliant with Constitutional prohibitions" (Stickney \& Marcus, 1984, p. 140).

Wolman v. Walter, 433 U.S. 229 (1977). Majority of the Supreme Court Justices favored "[1] the same standardized and diagnostic testing services to parochial school children as are provided to public school children if the testing is administered by public school employees...[2] therapeutic services at public expense if provided by public school employees at a site outside of the parochial school...[3] public purchase of secular texts and reusable workbooks for loan to parochial school students, but they balked at the provision of instructional materials, audiovisual equipment and transportation for field trips" (Stickney \& Marcus, 1984, p. 141).

1980 Committee for Public Education and Religious Liberty $v$. Regan, 100 S. Ct. 840 (1980): New York Superior Court justices split the vote on providing public monies to nonpublic schools "to support the paperwork, recordkeeping and other administrative costs associated with state-mandated testing requirements" (Stickney \& Marcus, 1984, p. 141). A caution was included not to use the case to determine whether public aid was permissible or not because of split vote. Later upheld as constitutional, 444 U.S. 646 (1980). "The statute provided reimbursement for actual cost of exclusively secular activities, and instituted procedures for substantiating [the use of] public funds [in] nonpublic schools" (Benway, 1983, p. 206). 
APPENDIX C

SURVEY PROTOCOL AND

RAW DATA 


\section{SURVEY OF SPECIAL NEEDS STUDENTS IN PRIVATE SCHOOLS January 1989}

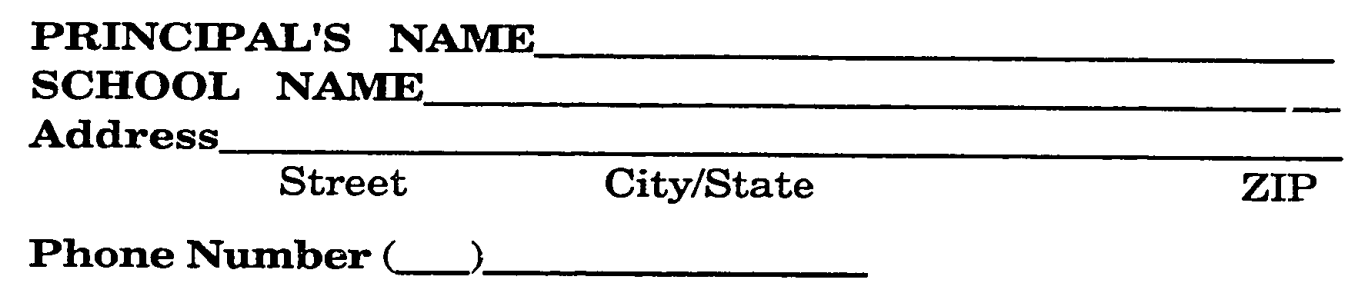

1. Please check the category that best describes your school: Non-religious orientation Religious orientation

2. How many K-6 students are enrolled for school year $1988^{\prime} 89$ $?$

3. (a) Do you have any students with special needs attending your school? Yes No

(b) If yes, indicate the kinds of special needs students you have enrolled:

students who have a learning disability students who are gifted/talented students who are culturally or linguistically different students who are struggling in school Other: (please list)

4. Are any students at your school working on an individualized learning plan such as an IEP? 


\section{Survey Page 2}

5. What currently happens in your school when a teacher or other staff member believes that a student is struggling to keep up in class?

(Check all that apply.)

parent is called siudent is referred to on-site personnel student is referred to public school district of residence teacher consults with on-site specialist/resource teacher discusses student with other faculty members Other: (please list)

6. Do you maintain contact with any public school or public school district? If so, please describe that contact.

I welcome any additional comments generated by this survey. (Indicate here if you would like your school to participate in the interview portion of the study.)

Thanks for taking the time to respond! A summary of responses will be sent to you during the spring.

Kathy Lindsay, Graduate Student

School of Education

Division of Special Education \& Rehabilitative Services

San Jose State University 
Raw Data from a Survey of Private Elementary Schools in Santa Clara County January 1989

\begin{tabular}{|c|c|c|c|c|c|c|}
\hline School & Religious & Census & Needs? & Types & Use IEP? & Referral \\
\hline 1 & Yes & 340 & No & 0 & $\mathrm{No}$ & $1,2,5$ \\
\hline 2 & Yes & 200 & $\mathrm{No}$ & 0 & $\mathrm{No}$ & $1,2,4$ \\
\hline 3 & No & 110 & No & 0 & No & $1,2,5$ \\
\hline 4 & Yes & 227 & No & 0 & No & $1,2,3,4,5$ \\
\hline 5 & No & 257 & No & 0 & No & 2,4 \\
\hline 6 & Yes & 184 & Yes & 1 & Yes & $1,2,+$ \\
\hline 7 & Yes & 233 & Yes & 1 & Yes & $1,2,3,4,5$ \\
\hline 8 & No & 206 & Yes & $1,2,3$ & No & $1,2,4,5$ \\
\hline 9 & Yes & 267 & Yes & $1,2,3,4$ & No & $1,3,4,5$ \\
\hline 10 & Yes & 100 & Yes & $1,2,3,4$ & Yes & $1,3,4,5$ \\
\hline 11 & No & 126 & Yes & $1,2,3,4$ & No & $1,2,4,5,+$ \\
\hline 12 & Yes & 253 & Yes & $1,2,3,4$ & No & $1,2,3,4$ \\
\hline 13 & No & 54 & Yes & $1,2,3,4$ & Yes & $1,2,3,4,5$ \\
\hline 14 & Yes & 380 & Yes & $1,2,3,4$ & Yes & $1,2,3,4$ \\
\hline 15 & No & 165 & Yes & $1,2,3,4$ & No & $1,2,4$ \\
\hline 16 & Yes & 182 & Yes & $1,2,3,4$ & No & $1,3,4,5$ \\
\hline 17 & Yes & 240 & Yes & $1,2,3,4$ & Yes & $1,3,5$ \\
\hline 18 & No & 35 & Yes & $1,2,3,4$ & $\mathrm{No}$ & 0 \\
\hline 19 & Yes & 66 & Yes & $1,2,3,4$ & $\mathrm{No}$ & $1,2,3,5$ \\
\hline 20 & Yes & 350 & Yes & $1,2,3,4$ & Yes & $1,2,3,4,5$ \\
\hline 21 & Yes & 305 & Yes & $1,2,3,4+$ & No & $1,2,3,4,+$ \\
\hline 22 & Yes & 285 & Yes & $1,2,3,4,+$ & No & $1,2,3,4,5$ \\
\hline 23 & Yes & 162 & Yes & $1,2,3,4,+$ & Yes & $1,2,4,5,+$ \\
\hline 24 & Yes & 159 & Yes & $1,2,3,4,+$ & Yes & $1,2,4,5$ \\
\hline 25 & Yes & 410 & Yes & $1,2,4$ & No & $1,2,3,4,+$ \\
\hline 26 & Yes & 190 & Yes & $1,2,4$ & Yes & $1,2,3,4,5$ \\
\hline 27 & Yes & 230 & Yes & $1,2,4$ & No & 1,3 \\
\hline 28 & Yes & 105 & Yes & $1,2,4$ & Yes & $1,3,5,+$ \\
\hline 29 & Yes & 450 & Yes & $1,2,4$ & Yes & $1,2,3,4,5$ \\
\hline 30 & Yes & 217 & Yes & $1,2,4$ & No & 1,5 \\
\hline 31 & Yes & 81 & Yes & $1,2,4$ & No & 1,5 \\
\hline 32 & Yes & 186 & Yes & $1,2,4$ & No & $1,2,3,4,5$ \\
\hline 33 & No & 26 & Yes & $1,2,4,+$ & Yes & $1,3,5$ \\
\hline 34 & Yes & 110 & Yes & $1,2,4,+$ & Yes & + \\
\hline 35 & No & 53 & Yes & $1,3,4,+$ & Yes & $1,2,4,5$ \\
\hline 36 & No & 25 & Yes & $1,4,+$ & Yes & $1,2,4,5$ \\
\hline 37 & No & 140 & Yes & 2 & 0 & 0 \\
\hline 38 & No & 345 & Yes & 2 & No & 1 \\
\hline 39 & No & 184 & Yes & $2,3,4$ & Yes & $1,2,5$ \\
\hline 40 & Yes & 180 & Yes & 3,4 & No & $1,3,5$ \\
\hline 41 & Yes & 67 & Yes & 4 & No & $1,3,5$ \\
\hline 42 & No & 77 & No & none & No & 1,3 \\
\hline
\end{tabular}




\section{APPENDIX D}

\section{INTERVIEW PROTOCOL}

AND

RAW DATA 
SCHOOL:

PERSON INTERVIEWED:

INTERVIEW DATE:

\section{INTERVIEW QUESTIONS/GUIDELINES}

(Response Sheet: Numbers =Y/N type; Letters=open-ended type)

How would you categorize your school's philosophy? (Optional)

If non-religious was checked on the survey form:

(1)Carden__ (2)Montessori__ or (3)Other:

If religious was checked on the survey form:

(4)Catholic__ (5)Protestant__ (6)Fundamenialist_ or (7)Other:

How many special needs students are there in each grade?

(8) $\mathrm{K} \_$(9)1 st_ (10)2nd_ (11)3rd_ (12)4th_ (13) 5 th__ (14)6th_

Identification of students with special needs:

(A)Who identifies special needs students in your school?

(AA)Criteria used by your school to identify LD:

(BB)Criteria for gifted/talented:

(CC)Criteria for LH/Gifted:

(15)Do personnel receive inservice or training for identification of students with special needs? (Y/N)

(BIf yes, please describe:

(16)If not, would it be accepted or useful? (Y/N) 


\section{Referral:}

(17)Do you have a formal (written) referral procedure in your school? (Y/N)

(C)Describe your referral process to personnel within the private school:

(D)Describe your referral process to the public school district:

\section{Assessment:}

(DD) What are your school's criteria to determine if assessment is needed:

If assessment for special needs is indicated, who would conduct the assessment?

(18)private school personnel:

(19)public school personnel:

(20)a combination of private and public personnel:

(21)other:

(22)Is assessment multidisciplinary: (Y/N)

(E)What disciplines are involved in assessment:

(F) What kinds of tests are used:

(23)Is assessment done in the student's primary language (if applicable)? (Y/N)

(G)How was primary language determined?

(24)Is follow-up assessment/testing done annually? _(25)triennially? _ or (26)at other specific intervals? _ (27)"None of the above."

\section{Placement:}

(EE)What placement options do you have in your school/:

(28)Is the parent involved in making placement decisions? ( $\mathrm{Y} / \mathrm{N})$

(H)Who else is involved in the placement decisions? ( 1 person or a group of people? Titles/positions) 
What is the basis for the placement decisions:

\# _ (29)formal testing (one test?)

(30)formal testing (more than one test?)

\# _ (31)informal testing _

\#_ (32)observations

(1)observations by whom?

\# _ (33)classroom performance

If applicable, rank by importance in decision-making:

(34)1 st in importance (35)2nd (36)3rd (37) 4 th

\section{Individualized education plan:}

(38)Is an individualized education plan written? (Y/N)

(J)Who writes it?

(K) Who is responsible to see that it is implemented?

(39)Is there a language component if the student is bilingual? ( $\mathrm{Y} / \mathrm{N})$

(L)What areas are addressed by the plan?

\section{Parent/s' rights:}

(M)Who is responsible to see that parents' rights are safeguarded during the entire process?

(N) How are the parents notified of student referral?

(O) How are the parents notified of the assessment procedure?

(40)Are the parents included in developing an individualized educational program? (Y/N)

(P)How are parents informed of their right to due process? 


\section{Services:}

(Q) Who provides the special education services if the student chooses to remain in the private school?

(R)Describe the services provided:

(S)What is the philosophy of the provider:

(41)Does the school sometimes recommend tutorial services? ( $\mathrm{Y} / \mathrm{N})$

(42)Does the school sometimes recommend public summer school? ( $\mathrm{Y} / \mathrm{N})$

(T)What other remediation services does the school recommend?

\section{Funding:}

(U) Who funds the assessment provided on site?

(v)What is the payment process?

(W)Who funds the special services provided on site?

(X) What is the payment process?

(Y)Questions specific to this school:

Thanks for answering my questions, what questions do you have?

(Z) Comments/Questions: 
Religious/Non-religious Orientation of Private Elementary Schools in Santa Clara County and Special Needs Student Census by Grade

"How would you categorize your schcol's philosophy?" (N=15)

If non-religious was checked on the survey form: $(n=3=20 \%)$ Carden(0)

Montessori(0)

Other:(3)

Coilege prep, whole child(2)

Developmental(1)

If religious was checked on the survey form: $(n=12=80 \%)$ Catholic(6)

Protestant

(2)

Fundamentalist(1)

$50 \%$

$17 \%$

Other:(3)

Jewish(2)

$8 \%$

Non-denominational(1)

$17 \%$

$8 \%$

"How many special needs students are there in each grade?" $(\mathrm{N}=8)$

(Numbers are estimated)

Kindergarten

First

39

Second

23

Third

25

Fourth

17

Fifth

10

Sixth

11

15

Note. If the number of schools responding is less than half of the fifteen schools in the sample, results are reported narratively rather than in percentages.

$\mathrm{N}$ is the number of schools responding to this question.

The number in ( ) refers to the number of schools giving a particular answer. 


\section{Identification of Students with Special Needs in Private Elementary}

\section{Schools in Santa Clara County.}

'Who identifies special needs students in your school?' $(\mathrm{N}=15)$

Teacher (15)

Entry screening (5) $\quad 33 \%$

Principal (3) 20\%

Parents (2) $13 \%$

Chapter 1 teacher (2) $13 \%$

Qthers mentioned: private agency, SRA test, tracking process, previous records, specialists.

'What criteria are used by your school to flag possible learning disabilities?' $(N=13)$

Attention problems (5)

Performance discrepancy (4) $\quad 31 \%$

Lack of progress (3) $23 \%$

Reading difficulties (2) $15 \%$

Classroom behavior (2) $15 \%$

Health problems (2) $15 \%$

Declining self-esteem (2) $\quad 15 \%$

Labels not used (2) $15 \%$

Qthers mentioned: following directions, math difficulties, hearing problems.

'What criteria are used by your school to flag possible gifted/talented students?'

$(\mathrm{N}=7)$ Reported narratively since $\mathrm{N}<50 \%$.

High reading ability

Higher general performance

High SRA scores, such as $<90 \%$

Program available to all

Program available in class
2 of 7 schools

2 of 7 schools

2 of 7 schools

2 of 7 schools

2 of 7 schools

'Do any students in your school fit the LH/gifted profile?" (N=9)

All schools acknowledged enrollment of such students.

"Do school personnel receive inservice or training for identification of students with special needs?' $(\mathrm{N}=15)$

$$
\begin{array}{ll}
\text { Yes (14) 93\%; } & \text { No (1) } 7 \%
\end{array}
$$

"If yes, please describe!" ( $N=14)$

Inservice (11)

$73 \%$

Workshops, faculty meetings, case studies

Outside specialists (10) $67 \%$

Classroom strategies (2) $\quad 13 \%$

Others mentioned: checklist mentioned, hiring interview.

The school indicating "no identification training" would like to have inservice.

Note. If the number of schools responding is less than half of the fifteen schools in the sample, results are reported narratively rather than in percentages.

$(\mathrm{N})$ is the number of schools responding to this question. 
Referral of Students with Special Needs in Private Elementary Schools in

Santa Clara County.

'Do you have a formal (written) referral procedure in your school?' $(\mathrm{N}=15)$

$$
\text { Yes (3) 20\%; No (12) } \quad 80 \%
$$

"Describe your referral process to personnel within the private school:" $(\mathrm{N}=15)$

Persons involved:

Teacher (15) $\quad 100 \%$

Principal (13) $\quad 87 \%$

Parent (12) 80\%

On-site specialist (7) $\quad 47 \%$

Outside specialist (4) 27\%

Documentation of referral was mentioned by only $13 \%$ of the schools. Referral procedures mentioned:

Teacher to principal

Teacher to principal to on-site specialist to parent

Teacher to principal to parent

Teacher to on-site specialist to parent to principal

Teacher to parent to on-site specialist to principal

Teacher to parent to on site specialist

"Describe your referral process to the public school district, if applicable:" (N=14)

Parent to public school/district (7) 50\%

Principal to public school/district (6) $43 \%$

Teacher to public school/district (1) $7 \%$

Note. If the number of schools responding is less than half of the fifteen schools in the sample, results are reported narratively rather than in percentages.

$\mathrm{N}$ is the number of schools responding to this question.

The number in () refers to the number of schools giving a particular answer. 


\section{Assessment of Students with Special Needs in Private Elementary Schools in Santa Clara County.}

'What are your school's criteria to determine if assessment is needed?' $(N=13)$

Teacher decision (7)

Principal decision (6)

$54 \%$

$46 \%$

Classroom strategies hadn't worked (6) $46 \%$

Qthers mentioned: specialist recommendation, SRA results.

"Who would conduct the assessment?" $(\mathrm{N}=14)$

Private agencies/individuals (10) $71 \%$

Public school personnel-usually off-site (8) $\quad 57 \%$

Private school personnel (3) 21\%

Combination private \& public (3) $21 \%$

"Is assessment multidisciplinary?" ( $\mathrm{N}=7$ ) Reported narratively since $\mathrm{N}<50 \%$. Yes: 3 of 7 schools

No: 4 of 7 schools

"What disciplines are involved in assessment?" $(\mathrm{N}=7)$ Reported narratively since $\mathrm{N}<50 \%$.

Learning disabilities specialist

3 of 7 schools

Speech \& language specialist

3 of 7 schools

Occupational therapist

2 of 7 schools

Others mentioned: psychologist, medical professionals, counselor.

"What kinds of tests are used?" (N=6) Reported narratively since $\mathrm{N}<50 \%$.

Tests (number of schools in parentheses) Woodcock-Johnson Test of

Psycholinguistic Abilities (3), KeyMath (2), Peabody Individual Achievement Tests

(1), Brigance (2), Diagnostic Survey (1), Slingerland Pre-reading (2), Informal

Reading Inventory (1), Frostig (1), Illinois Test of Psycholinguistic Abilities (1),

Detroit Test of Learning Abilities (1), Peabody Picture Vocabulary Test-Revised (1),

Wide Range Achievement Test (1), Spache (1), Durrell Reading Analysis (1),

Bruinks-Oeseretsky (1).

"Is assessment done in the student's primary language?" $(\mathrm{N}=3)$ Reported narratively, $\mathrm{N}<50 \%$

Yes 3 of 3 schools. 'How is primary language determined?' Changed to 'how is home language
determined?' $(\mathrm{N}=11)$

Initial parent interview (8) $73 \%$

Initial screening (2) $18 \%$

Pre-K screening choice (Spanish or English) 1 school

Not documented (4)

Documented on application form (4)

$36 \%$

$36 \%$

'When is follow-up assessment/testing done?' ( $\mathrm{N}=7)$ Reported narratively since $\mathrm{N}<50 \%$.

$\begin{array}{ll}\text { As needed } & 4 \text { of } 7 \text { schools } \\ \text { Pre/post test } & 2 \text { of } 7 \text { schools } \\ \text { Quarterly } & 1 \text { of } 7 \text { schools }\end{array}$

Note. If the number of schools responding is less than half of the fifteen schools in the sample, results are reported narratively rather than in percentages. $N$ is the number of schools responding to this question. The number in () refers to the number of schools. 
Placement of Students with Special Needs in Private Elementary Schools in Santa Clara County.

'What placement options are available in your school?' (N=15)

Ability grouping within grade/class (12) $80 \%$

Ability grouping across grades (9) $75 \%$

Cooperative learning (6) $40 \%$

Peer tutoring (5) 33\%

Curriculum/homework modification (4) $27 \%$

Chapter 1 teachers (2) $\quad 13 \%$

Retention (2) $13 \%$

Others mentioned: volunteer tutoring, staff tutoring, program variety, developmental kindergarten, junior kindergarten, cross grade tutors, special day class, completely individualized program for all.

Where is happening? $(\mathrm{N}=8)$ Reported narratively since $\mathrm{N}<50 \%$.
In class only
Pull-out only
2 of 8 schools
3 of 8 schools
3 of 8 schools

Both in class \& pull-out

"Is the parent involved in making placement decisions?" $(\mathrm{N}=15)$

$$
\text { Yes (10) 67\%; } \quad \text { No (5) 33\% }
$$

'Who else in involved in making the placement decisions?' (N=15)

Teachers (15) $100 \%$

Principal (10) 67\%

Ouiside resources (3) $33 \%$

Chapter 1 teacher (2) $13 \%$

'What is the basis for the placement decisions?' $(\mathrm{N}=14)$

$\begin{array}{lr}\text { Observations (14) } & 100 \% \\ \text { Classroom performance (14) } & 100 \% \\ \text { Informal testing (13) } & 93 \% \\ \text { Formal testing-more than } 1 \text { test (11) } & 79 \% \\ \text { Formal testing-1 test (4) } & 29 \%\end{array}$

'Ranked by order of importance in making decisions:' $(\mathrm{N}=14)$

1. Classroom performance-tied for most important (7)

2. Observations-tied for most important (7)

3. Informal testing (4)

4. Formal testing (4)

'Who conducts classroom observations?' $(\mathrm{N}=14)$

Classroom teacher (14) $100 \%$

Principal (11) $\quad 79 \%$

Specialist, on-site or other (9) $64 \%$

Note. If the number of schools responding is less than half of the fifteen schools in the sample, results are reported narratively rather than in percentages.

$\mathrm{N}$ is the number of schools responding to this question.

The number in ( ) refers to the number of schools responding. 
Individualized Education Plans for Special Needs Students in Private

Elementary Schools in Santa Clara County.

"Is an individualized education plan written?" $(\mathrm{N}=14)$

Yes (9) 64\%; No (5) $36 \%$

"Who writes the plan?" $(\mathrm{N}=9)$

Specialist (5)

Classroom teacher (5)

Principal (2)

$56 \%$

$56 \%$

Others mentioned: evaluator, parent.

$22 \%$

"Who is responsible to see that the plan is implemented?' $(\mathrm{N}=9)$

Teacher (6)

$67 \%$

Principal (3)

$33 \%$

Others mentioned: Learning Assistance Teacher in the case of the self-contained special day class.

"Is there a langunge component if the student is bilingual?" $(\mathrm{N}=2)$

Reported narratively since $\mathrm{N}<50 \%$.

Yes 2 of 2 schools

"What areas are addressed by the plan?' ( $\mathrm{N}=5)$ Reported narratively since $\mathrm{N}<50 \%$.

Academic areas $\quad 5$ of 5 schools

Social area 2 of 5 schools

Others mentioned: religious area, emotional area, cognitive area, motor area.

Note. If the number of schools responding is less than half of the fifteen schools in the sample, results are reported narratively rather than in percentages.

$\mathrm{N}$ is the number of schools responding to this question.

The number in ( ) refers to the number of schools giving a particular answer. 
Safeguarding Parent/s' Rights of Special Needs Students in Private

Elementary Schools in Santa Clara County.

'Who is responsible for seeing that parent/s' rights are safeguarded during the entire process?' $(\mathrm{N}=14)$

Principal only (12)

Teacher only (1)

Teacher \& principal (1)

$86 \%$

$7 \%$

$7 \%$

Others mentioned: Learning assistance teacher \& principal.

'How are the parents notified of student referral?" (N=14)

Verbally

Teacher (10) $71 \%$

Written

Principal (2) 14\%

Teacher (5) $\quad 36 \%$

Letter (2) $\quad 14 \%$

Priv. agcy (2) $14 \%$

Others mentioned: cum folder, letter if referred outside school.

"How are parents notified of the assessment procedure?" (N=7)

Reported narratively since $\mathrm{N}<50 \%$.

Verbal only

Written only

Both verbal \& written
5 of 7 schools

4 of 7 schools

2 of 7 schools

"Are the parents included in developing an individualized educational plan?" $(\mathrm{N}=7)$ Reported narratively since $\mathrm{N}<50 \%$.

Yes 7 of 7 schools

"How are the parents informed of their right to due process?"

This question is not relevant to private schools since they usually require parent involvement in daily classroom work. The responses are disqualified because of interviewer non-reliability: presented differently at different times.

Note. If the number of schools responding is less than half of the fifteen schools in the sample, results are reported narratively rather than in percentages.

$\mathrm{N}$ is the number of schools responding to this question.

The number in ( ) refers to the number of schools. 
Services Available for Students with Special Needs in Private Elementary Schools in Santa Clara County.

"Who provides the special education services if the student chooses to remain in the private school, yet would qualify for special education services in the public school?" $(\mathrm{N}=15)$

Private agency on-site (9) 60\%

Private school services (6) $40 \%$

Public school on-site (6) $40 \%$

Partial day at public school (4) 27\%

Volunteer tutors (3) $20 \%$

Speech/language specialist (2) $13 \%$

Others mentioned: staff tutoring, psychologist, occupational therapist.

"Describe the services provided:" $(\mathrm{N}=15)$

$1-1$ tutoring/therapy (15) $\quad 100 \%$

Chapter 1 services (4) 27\%

Speech/language (3) 20\%

Counseling (2) 13\%

Mobile van (2) $13 \%$

Others mentioned: self-contained special day class, English as a

second language instruction, bilingual services.

"What is the philosophy of the provider?" $(\mathrm{N}=8)$

Multisensory (5)

Unknown (2)

$63 \%$

$25 \%$

Developmental (1) $\quad 12 \%$

'Does the school sometimes recommend tutorial services?" ( $N=15)$ Yes (14) 93\%; No (1) $\quad 7 \%$

"Does the school sometimes recommend public summer school?" $(\mathrm{N}=15)$

$$
\text { Yes (10) 67\%; } \quad \text { No (5) } \quad 33 \%
$$

"What other remediation services does the school recommend?" $(\mathrm{N}=14)$

Private agencies (6)

Community services (3) $21 \%$

Counselors (2) $14 \%$

Other put. schools (2) $14 \%$

Others mentioned: occupational therapy, speech/language, staff tutoring.

Note. If the number of schools responding is less than half of the fifteen schools in the sample, results are reported narratively rather than in percentages. $N$ is the number of schools responding to this question. The number in () refers to the number of schools. 
Funding for Services for Special Needs Students in Private Elementary Schools in Santa Clara County.

$\begin{array}{lc}\text { 'Who funds the assessment services provided on site?" (N=10) } & 80 \% \\ \text { Parents (8) } & 40 \% \\ \text { School (4) } & 20 \% \\ \text { Public school (2) } & \\ & 100 \% \\ \text { 'What is the payment process?' (N=10) } & 40 \% \\ \text { Individual to private agency (10) } & 20 \% \\ \text { School budget (4) } & \\ \text { Public school (2) } & 93 \% \\ & 53 \% \\ \text { 'Who funds the special services provided on site?' (N=15) } \\ \text { Parents (14) } & 27 \% \\ \text { School budget (8) } & 27 \% \\ \text { Public school (4) } & \\ \text { Volunteers (4) } & 79 \% \\ & 64 \% \\ \text { 'What is the payment process?' (N=14) } & 57 \% \\ \text { Individual to private agency (11) } & \\ \text { Parents (9) } & \end{array}$

Note. If the number of schools responding is less than half of the fifteen schools in the sample, results are reported narratively rather than in percentages.

$\mathrm{N}$ is the number of schools responding to this question.

The number in ( ) refers to the number of schools giving a particular answer. 
APPENDIX E

RESEARCH AGREEMENT 


\section{AGREEMENT TO PARTICIPATE IN RESEARCH SAN JOSE STATE UNIVERSITY}

\section{RESPONSIBLE INVESTIGATOR: Kathleen R. Lindsay}

\section{TITLE OF PROTOCOL: Special Needs Students in Private Elementary Education}

I have been asked to participate in a research study that is investigating how the procedures of identification, referral, assessment, placement, service delivery, and due process, as identified in P.L. 94-142, are being implemented in private schools in Santa Clara County. The results of this study should further our understanding of how special needs students are identified and accommodated in the private elementary schools of Santa Clara County.

I understand that

1) During an interview of thirty to forty-five minutes I will be asked to describe any of the above procedures that are used in my school.

2) There are no known risks involved with this study.

3) I will benefit from the knowledge gained by becoming more sensitive to special needs students and by increasing my awareness of the law directly affecting them (P.L. 94-142).

4) The results from this study may be published, but any information from this study that can be identifled with me, personally, will remain confidential and will be disclosed only with my permission of as required by law.

5) Any questions about my paiticipation in this study will be answered by Kathy Lindsay, (408) 446-4125. Complaints about the procedures may be presented to Dr. Marcia Henry, (408) 924-3681. For questions or complaints about research subject's rights, or in the event of research-related injury, contact Serena Stanford, Ph.D. (Associate Academic Vice President for Graduate Studies \& Research) at 924-2480.

6) My consent is given voluntarily without being coerced; I may refuse to participate in this study or in any part of this silıdy, and I may withdraw at any time, without prejudice to my relations with San Jose State University.

7) I have recelved a copy of this consent form for my flle.

MY SIGNATURE INDICATES THAT I HAVE READ THE INFORMATION PROVIDED ABOVE AND THAT I HAVE DECIDED TO PARTICIPATE IN THIS STUDY. 